\title{
The effect of biotin interference on the results of blood hormone assays
}

\author{
Magdalena Ostrowska' ${ }^{1}$ Zbigniew Bartoszewicz², Tomasz Bednarczuk², Klaudia Walczak², \\ Wojciech Zgliczyński ${ }^{1}$, Piotr Glinicki ${ }^{1}$
}

${ }^{1}$ Department of Endocrinology, Centre of Postgraduate Medical Education, Warsaw, Poland

${ }^{2}$ Department of Internal Medicine and Endocrinology, Medical University of Warsaw, Poland

\begin{abstract}
Approximately $70 \%$ of medical decisions are made based on results of laboratory investigations. Immunochemical methods are used most commonly in routine laboratory diagnostics of endocrine disorders. Those methods are limited by susceptibility of the immunochemical reaction to various interferences. Interference may be caused by the presence of autologous antibodies, heterophilic antibodies, or paraproteins in the blood serum, by cross-reactions with similar reagents, haemolysis, significant lipidaemia, or hyperbilirubinaemia. Some recent reports have indicated a significant effect of biotin on the reliability of laboratory investigations. Biotin is a water-soluble vitamin belonging to the B group. It is present in popular dietary supplements - alone or as a component of multi-vitamin formulas — and it is advertised as a remedy to falling out and fragility of hair and nails. Due to its low molecular weight and a strong affinity to streptavidin, biotin is used in many immunochemical tests. Due to a strong and stable bond of streptavidin and biotin, analytical methods using the streptavidin (avidin)-biotin system are characterised by superior sensitivity, and they allow determination of very low levels of the tested substance in biological material. The presence of exogenous biotin in a sample may cause interference when using tests that utilise the streptavidin (avidin)-biotin system. Interference of biotin with immunochemical tests depends on several factors: the construction of the immunochemical test, the dose used by the patient, the biotin concentration in the sample, and most of all — the time from the last dose to the collection of biological material for laboratory testing. In this paper we present some practical recommendations and a procedure to be followed in the case of suspected interference of biotin in immunochemical assays, for clinicians and laboratory diagnosticians. (Endokrynol Pol 2019; 70 (1): 102-111)
\end{abstract}

Keywords: biotin; interference; immunochemistry; dietary supplements; anti-streptavidin antibodies

\section{Introduction}

Approximately $70 \%$ of medical decisions are made based on results of laboratory investigations [1]. A precise and reliable result of a laboratory investigation allows a physician to make a correct diagnosis and to choose an appropriate therapeutic method. Immunochemical methods are used most commonly in routine laboratory diagnostics of endocrine disorders. They are extensively used because of their advantages, including: high sensitivity, precision, specificity, direct determination of the level of a selected parameter in the serum, plasma, or other biological material, and a relatively short waiting time for the result [2]. Due to enormous technological progress, the majority of these techniques are fully automated, allowing determination of a broad spectrum of laboratory parameters, including: hormones, antibodies, cancer markers, organ injury and/or dysfunction markers, viral infection markers, inflammatory and tissue necrosis markers, and some drugs and vitamins. They include isotope-based methods: radioimmunological assay (RIA) and immunoradiometric assay (IRMA), currently applied for approx. 15-20\% of immunochemical determinations. The vast majority of immunochemical determinations used currently in clinical practice are based on a numerous group of non-isotope-based methods, such as: immunoenzymatic method (ELISA), immunochemiluminescence method (CLIA), immunoelectrochemiluminescence method (ECLIA), and others. These methods are limited by susceptibility of the immunochemical reaction to various interferences. Those interferences may be caused by the presence of autologous antibodies in a patient's serum and by in vivo formation of macro-molecules, presence of heterophilic antibodies against animal IgG (HAMA - human anti-mouse antibody, or HAAA - human anti-animal antibody), cross-reactions, or other common factors, including: haemolysis, significant lipidaemia, or hyperbilirubinaemia. Recent reports indicate a possibility of interference caused by biotin. The compound was a cause of false high or false low results of assays based on the streptavidin (avidin)-biotin system [3, 4]. 


\section{When should biotin interference be suspected in immunochemical assays?}

Biotin interference may occur in various immunochemical tests - both manual and automated - using the streptavidin (avidin)-biotin bond in their construction.

The streptavidin (avidin)-biotin bond is one of the strongest non-covalent links that is resistant to $\mathrm{pH}$ changes, repeated washing, chalotropic factors, and extreme conditions of the reaction (e.g. temperature). Due to the stability and high sensitivity allowing determination of minor levels of a tested analyte $(\mathrm{ng} / \mathrm{mL}, \mathrm{pg} / \mathrm{mL})$ in a biological material, analytical methods commonly use the streptavidin (avidin)-biotin (SA/B) system. Because of low molecular weight, introduction of a molecule of biotin does not change the properties of numerous compounds, such as: proteins, hormones, or antibodies, used in immunochemical tests, and the biotinylation itself does not cause any methodological difficulties. Avidin, an alkaline protein present in egg white, and its non-glycolysed variant - streptavidin, produced by the Streptomyces avidini strain - are easy to obtain.

Biotin interferences are a problem in patients with high blood biotin level, resulting from the use of the compound as a dietary supplement, and in patients treated with high doses of biotin.

\section{Biotin}

Biotin (vitamin $\mathrm{H}, \mathrm{B} 7, \mathrm{~B} 8$ ) is a water-soluble vitamin belonging to the $\mathrm{B}$ group. It is synthesised by intestinal microflora, and therefore its deficiency is rare and mostly associated with the use of broad-spectrum antibiotics. Biotin is necessary for life. The compound is a co-enzyme for various enzymes participating in numerous metabolic pathways. It is an important co-enzyme of carboxylases engaged in gluconeogenesis, synthesis of nucleic acids and fatty acids, the Krebs cycle, and degradation of leucine. Exogeneous biotin is rapidly absorbed by intestinal mucosa, and it is eliminated mainly with urine, either in unchanged form or as metabolites: bisnorbiotin, biotin sulphone, bisnorbiotin-methyl-ketone, and others [5]. Its half-life in blood is approx. 110 minutes [6]. The compound is present in the following foods: pork, liver, egg yolk, soya beans, almonds, and leafy vegetables. The daily demand for biotin in children increases with age, and in adults it is $30-75 \mu \mathrm{g}$ [7]. Biotin is present in some popular dietary supplements, alone or as a component in multi-vitamin formulas. It is advertised as a remedy for loosing hair and for fragility of hair and nails. In Poland, the most popular dietary supplements contain between $0.3 \mathrm{mg}$ and $10 \mathrm{mg}$ of biotin, which highly exceeds the mean daily demand (by 6 to 200 times). People using high doses of biotin are at particularly high risk of that type of interference. Moreover, biotin may be bought in unlimited amounts, and considering its exceptionally low toxicity, the risk of overdose is also very low.

The other group at risk of biotin interference are patients treated with high doses of biotin (5-300 mg/day) in the course of therapy of congenital metabolic diseases: biotinidase deficiency, thiamine transporter-2 deficiency, holocarboxylase synthetase deficiency [8]. At higher doses biotin is used in neonates and infants, particularly if a metabolic disease is suspected, [9] and in adults suffering from multiple sclerosis (SM) and other demyelinisation diseases [10]. The legitimacy of applying biotin in the treatment of some of those diseases is questioned. Some biotin-containing medicinal products were withdrawn from the market because of their minor therapeutic effect. In Poland the problem of biotin interference associated with those products is practically non-existent because medical procedures involving the use of biotin as a medicinal product are not approved there.

\section{The mechanism of biotin interference in immunochemical assays}

The presence of exogenous biotin in a sample may cause interference when using tests that utilise the SA/B system. The first reports of that type of interference were published in 1996. However, only recently the problem has been of greater interest because increasingly detected discrepancies between results of hormonal assays and the clinical presentation. The discrepancy could be potentially associated with extensive use of biotin-containing dietary supplements.

Immunochemical methods are based on a specific reaction between an epitope (3- 8 amino acids) on the surface of the antigen, and a corresponding binding site in the molecule of an antibody. Antibodies used in tests recognise a precisely determined chemical structure of the epitope and not the biological activity of the test substance. The use of various systems of detection (markers) allows tracking of the immunological reaction and quantitative determination of the concentration or titre of the test substance. There are two main types of methods used in routine immunological tests. The non-competitive method uses two antibodies: up-taking and detective, which recognise two different determinants of an antigen. A complex is formed: up-taking antibody-antigen-detective antibody; this system increases the sensitivity and specificity of the assay. It is referred to as the "sandwich" type. The other type of reaction uses a labelled antigen, or its analogue, as a detective factor, which competes with the test antigen (non-labelled) for binding sites in molecules of the antibody. This is a com- 
petitive method. The following complexes are formed: labelled antigen-antibody, and test antigen-antibody. Immunochemical reactions may take place in the liquid phase (the homogeneous type of reaction) or in the solid phase (currently the most commonly used), e.g. in a test tube, on a slide, or with paramagnetic micro-molecules (the heterogeneous type of reaction).

In a sandwich test (non-competitive) exogenous biotin binds to streptavidin-coated micro-molecules of the solid phase, allowing further binding of the biotinylated antibody-analyte-labelled antibody complex. That results in reduced intensity of the measured marker signal, and in consequence leads to false low result because in non-competitive methods the signal-to-concentration relationship is proportional to the concentration of the test analyte. In the competitive method, excess of exogenous biotin also binds to streptavidin-coated micro-molecules of the solid phase, thus blocking binding of both biotinylated antibody test analyte, and biotinylated antibody-labelled analyte complexes. Similarly to the sandwich test, it results in decreased intensity of the measured signal. But in this case the obtained result will be false high, because the number of complexes in the solid phase is inversely proportional to the concentration of the test analyte. Figures 1-4 present diagrams explaining the mecha-
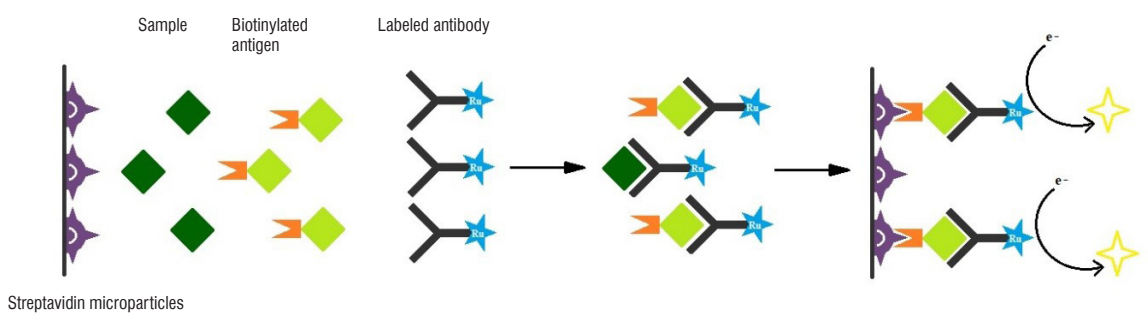

Figure 1. Diagram of a competitive method

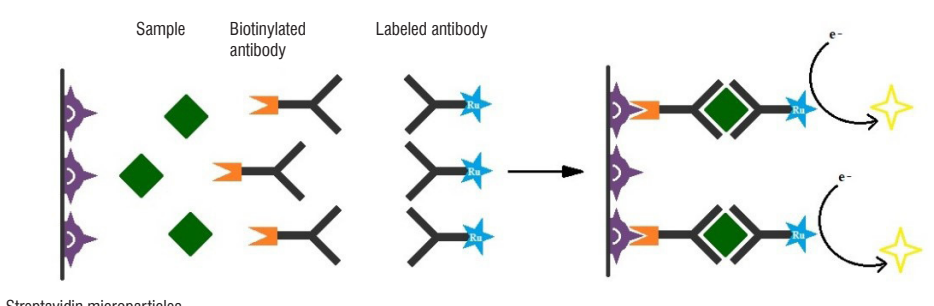

Figure 2. Diagram of a non-competitive method

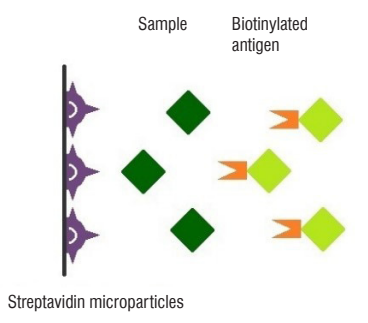

$\begin{array}{ll}\text { Labeled antibody } & \begin{array}{l}\text { Excess } \\ \text { dietary biotin }\end{array}\end{array}$

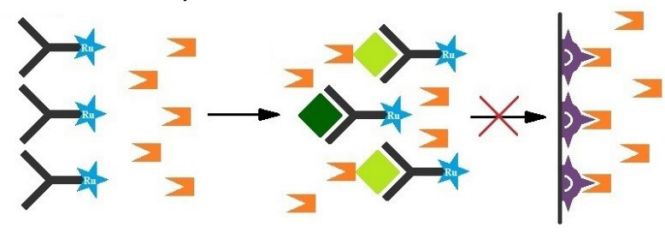

Figure 3. Competitive test — high biotin level
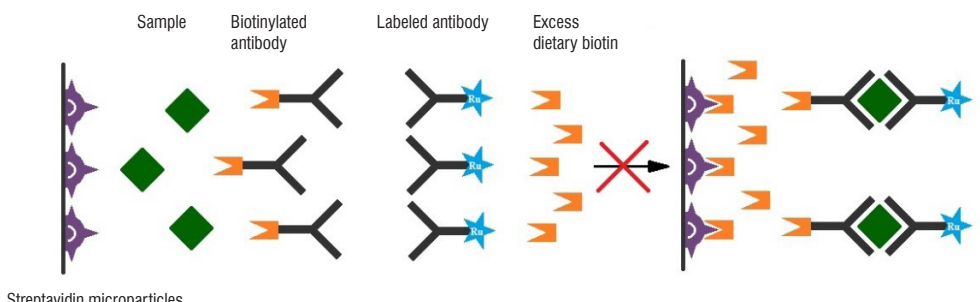

Figure 4. Non-competitive test — high biotin level 
nisms of immunochemical reactions (competitive and sandwich), as well as the mechanism of interference with high biotin levels in both methods [11].

Non-competitive tests (sandwich) are used for determination of large hormone molecules: thyroid stimulating hormone (TSH), luteinizing hormone $(\mathrm{LH})$, follicle-stimulating hormone (FSH), human chorionic gonadotropin (hCG), parathyroid hormone (PTH), insulin-like growth factor 1 (IGF-1), insulin, thyroglobulin, and C-peptide. In this type of test susceptible to high biotin content (and containing the SA/B system) we observe false negative (low) results of assayed hormones.

Competitive tests are used for determination of concentration/titre of small hormone molecules and antibodies: thyroxine (T4/fT4), triiodothyronine (T3/fT3), vitamin D3 (25-OH-D3), steroid hormones (e.g. androstenedione, aldosterone, 17- $\mathrm{OH}$-progesterone), and antibodies: TSH receptor autoantibodies (TRAb), anti-thyroid peroxidaseantibodies (a-TPO), and thyroglobulin antibodies (a-Tg). In this type of test susceptible to high biotin content (and containing the SA/B system) we observe false positive (high) results of assayed hormones and antibodies.

\section{Immunochemical tests based on the streptavidin (avidin)-biotin system - susceptible to biotin interference}

Six out of the seven currently most often used immunochemical analysers are equipped with tests based on the streptavidin (avidin)-biotin system. In the Elecsys ${ }^{\circledR}$ analyser (from Roche) 81 of immunochemical tests out of the 81 that are available are susceptible to biotin interference, in the Vitros ${ }^{\circledR}$ analyser (from Ortho) - 43 (29), in Dimension $\AA$ (from Siemens) - 26 (21), in Centaur (from Siemens) - 67 (18), in Access ${ }^{\circledR}$ and DXI ${ }^{\circledR}$ (from Beckman Coulter) - 48 (14), and in Architect i2000® (from Abbott) - 46(2). The Liaison XL® analyser (from DiaSorin) is an exception; none of 42 available immunochemical tests uses the streptavidin (avidin)-biotin reaction. Summing up, of 353 available tests 165 may be susceptible to biotin interference. That corresponds to $47 \%$ of all available tests. Table I presents immunochemical tests from various manufacturers, used in laboratory diagnostics of endocrine disorders, and susceptible to biotin interference. Some manufacturers mention biotin as one of the interfering factors in reagent pack leaflets. Depending on the manufacturer and the type of used test, the threshold level of biotin above which it will interfere with the assay is between 2.4 and $1968 \mu \mathrm{g} / \mathrm{L}$ (between 10 and 8200 $\mathrm{nmol} / \mathrm{L}$ ) (in the previously mentioned analysers) [12]. For the majority of tests that threshold value is $<51 \mu \mathrm{g} / \mathrm{L}$ [13]. Unfortunately, that kind of data is not available for all tests. Manufacturers also do not indicate what doses of the vitamin used by a patient those concentrations refer to [4]. Some more precise information on the effect of various concentrations of biotin on determination of selected parameters was provided by the in vitro experiment carried out on the Elecsys $\AA$ analyser from Roche, which simulated administration of biotin in doses of 5-10 $\mathrm{mg}$ and 100-300 $\mathrm{mg}$, which corresponded to serum biotin levels of $15.6 \mu \mathrm{g} / \mathrm{L}, 31.3 \mu \mathrm{g} / \mathrm{L}$, and $500 \mu \mathrm{g} / \mathrm{L}$.

Table I. Immunochemical tests susceptible to biotin interference, used in biochemical endocrinological diagnostics

\begin{tabular}{|c|c|c|c|c|}
\hline \multirow{2}{*}{$\begin{array}{l}\text { Immunochemistry } \\
\text { analyser }\end{array}$} & \multicolumn{4}{|c|}{ Endocrine laboratory tests } \\
\hline & $\begin{array}{l}\text { Number } \\
\text { of tests }\end{array}$ & $\begin{array}{l}\text { Vulnerable to } \\
\text { biotin interference }\end{array}$ & $\begin{array}{c}\text { Biotin interference } \\
\text { threshold }[\mu \mathrm{g} / \mathrm{L}]\end{array}$ & Test and direction of interference \\
\hline Roche Elecsys & 46 & 46 & $5.04-117.84$ & $\begin{array}{l}\text { TSH } \downarrow \text { TG } \downarrow \text { FSH } \downarrow \text { LH } \downarrow \text { SHBG } \downarrow \text { PTH } \downarrow \text { PRL } \downarrow \text { hCG } \downarrow \text { fT } 4 \uparrow \text { T4 } \uparrow \\
\mathrm{fT} 3 \uparrow T 3 \uparrow \text { CORT } \uparrow \mathrm{E} 2 \uparrow \mathrm{PRG} \uparrow \text { Testost } \uparrow \mathrm{DHEAS} \uparrow 25 \mathrm{HD} \uparrow \\
\mathrm{TGAb} \uparrow \mathrm{TPOAb} \uparrow \mathrm{TSHRAb} \uparrow\end{array}$ \\
\hline Ortho Vitros & 17 & 11 & $4.8-19.68$ & $\begin{array}{l}\text { TSH } \downarrow \text { FSH } \downarrow \text { LH } \downarrow \text { iPTH } \downarrow \text { PRL } \downarrow \text { hCG } \downarrow \text { PRG } \uparrow \mathrm{E} 2 \uparrow \text { Testost } \uparrow \\
\text { CORT } \uparrow 250 H D \uparrow\end{array}$ \\
\hline $\begin{array}{l}\text { Siemens } \\
\text { Dimension }\end{array}$ & 10 & 9 & $49.20-196.80$ & 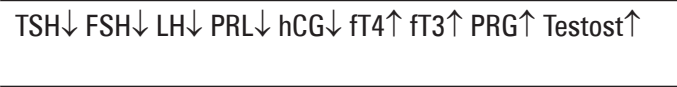 \\
\hline Siemens Centaur & 20 & 4 & $98.16-981.60$ & SHBG $\downarrow$ fT4 $\uparrow \mathrm{iPTH} \uparrow \mathrm{DHEAS} \uparrow$ \\
\hline $\begin{array}{l}\text { Beckman Coulter } \\
\text { Access/DXI }\end{array}$ & 26 & 6 & $98.16-240.00$ & $\mathrm{TG} \downarrow \mathrm{TGAb} \downarrow \mathrm{TPOAb} \downarrow \mathrm{fT} 4 \uparrow \mathrm{fT} 3 \uparrow \mathrm{TT} 3 \uparrow$ \\
\hline $\begin{array}{l}\text { Abbott Architect } \\
\text { i2000 }\end{array}$ & 18 & 1 & No data & $250 \mathrm{HD}$ \\
\hline DiaSorin Liaison XL & 20 & 0 & - & - \\
\hline
\end{tabular}

fT4 — free thyroxine; T4 — thyroxine; fT3 — free triiodothyronine; T3 — triiodothyronine; CORT — cortisol; E2 — estradiol; PRG — progesterone; Testost — testosteron; DHEAS — dehydroepiandrosterone; $250 \mathrm{HD}$ — calcifediol; TGAb — thyroglobulin autoantibody; TPOAb — anti-thyroid peroxidase autoantibody; TSHRAb — thyrotropin (TSH) receptor antibody; LH — luteinizing hormone; hCG — human chorionic gonadotropin; FSH — follicle-stimulating hormone; PTH — parathyroid hormone; SHGB - sex hormone binding globulin 
Troponin $\mathrm{T}$ and anti-thyroid antibodies were the most susceptible to low biotin levels, and all tests proved to be significantly susceptible to interference of high biotin levels. The experiment demonstrated a high variability of test susceptibility to the interference caused by the presence of biotin in the serum, and provided more precise data compared to those in the manufacturer's leaflet [14]. The in vitro experiment was also done with the Dimension ${ }^{\circledR}$ analyser from Siemens. The experiment investigated the effect of various concentrations of biotin in patients' samples based on results of immunodiagnostic tests. No interference was demonstrated for biotin concentrations between 50 and $200 \mu \mathrm{g} / \mathrm{L}$. The biotin level of $300 \mu \mathrm{g} / \mathrm{L}$ interfered with assays of troponin and fT3, and levels over $400 \mu \mathrm{g} / \mathrm{L}$ interfered with assays of troponin, digoxin, $\mathrm{N}$-terminal pro b-type natriuretic peptide (NT-pro-BNP), fT3, fT4, TSH, progesterone, and oestradiol [15]. Although both experiments offered numerous pieces of valuable information, they were conducted with "pure" biotin, and they might not reflect the conditions existing in a patient's sample, where, besides biotin itself, there were also its metabolites $[8,15,16]$.

Interference of biotin with immunochemical tests depends on several factors: the construction of the immunochemical test, the dose used by a patient, the biotin concentration in a sample, and, most of all, the time from the last dose to collection of biological material for laboratory testing. The serum level of biotin ingested with food is $0.12-0.36 \mathrm{nmol} / \mathrm{L}(0.0288-0.0864 \mu \mathrm{g} / \mathrm{L})$ and does not interfere with tests using the SA/B system [5, 17]. Li et al. designed a study in which six healthy people took biotin at the dose of $10 \mathrm{mg}$ for seven days. The mean baseline biotin level was $0.774 \mu \mathrm{gL}(774 \mathrm{pg} / \mathrm{mL})$, and after seven days the level was $3.6 \mu \mathrm{g} / \mathrm{L}$ (3600 pg/mL). On the day 7 interference was observed for $39 \%$ (9 of 23) of the tests using the SA/B system. Another seven days after discontinuation of biotin supplementation, no changes in test results were observed [11]. Biotin in a single dose of $30 \mathrm{mg}$ interferes with assays of fT4, fT3, and thyroglobulin (the analyser from Beckman Coulter), and the interference is maintained for up to $24 \mathrm{~h}$ [18]. Three days after discontinuation of biotin, levels of TSH, $\mathrm{T} 4$, fT4, and T3 were back to normal in a patient who had been administered $100 \mathrm{mg}$ of biotin three times a day [19]. For children and neonates treated with biotin at doses of $15-20 \mathrm{mg} / \mathrm{kg} /$ day, TSH, fT4, and T3 levels were back to normal within 24-48 h of discontinuation of supplementation, and a false high titre of antibodies against the TSH receptor was maintained for up to seven days.

\section{Why is biotin interference important in the diagnostics of thyroid diseases?}

False low TSH levels, false high levels of free thyroid hormones, and the presence of antibodies against the TSH receptor (TRAb) may suggest hyperthyroidism, in absence of any clear clinical symptoms. Table II presents test results of thyroid hormones levels in the presence of high biotin concentration (developed after Kummer et al. [20]).

\section{Biotin interference in hormonal assays - case studies}

Papers presenting cases of biotin interference in immunochemical assays have emerged recently. Most com-

Table II. Thyroid hormone levels in the presence of a high biotin level [20]

\begin{tabular}{|c|c|c|c|c|c|c|}
\hline & Patient 1 & Patient 2 & Patient 3 & Patient 4 & Patient 5 & Patient 6 \\
\hline Sex / age & $\mathrm{F} / 9 \mathrm{yr}$ & $\mathrm{F} / 2 \mathrm{yr}$ & $\mathrm{M} / 2 \mathrm{yr}$ & $\mathrm{M} / 5 \mathrm{mo}$ & $\mathrm{M} / 1 \mathrm{mo}$ & $\mathrm{M} / 1 \mathrm{mo}$ \\
\hline Biotin dose [mg/kg/day] & 10 & 14 & 15 & 2 & 7 & 8 \\
\hline \multicolumn{7}{|c|}{ Laboratory results } \\
\hline \multicolumn{7}{|l|}{ During biotin treatment } \\
\hline TSH $[\mu \mathrm{IU} / \mathrm{mL}]$ & 0.05 & 0.02 & 0.04 & 0.02 & 0.08 & 0.03 \\
\hline $\mathrm{fT}_{4}[\mathrm{ng} / \mathrm{dL}]$ & 6.24 & $>7.77$ & $>7.77$ & $>7.77$ & $>7.77$ & $>7.77$ \\
\hline $\mathrm{T}_{3}[\mathrm{ng} / \mathrm{dL}]$ & $>6.5$ & - & $>6.5$ & $>6.5$ & $>6.5$ & - \\
\hline TRAb [IU/L] & 38.6 & $>40.0$ & $>40.0$ & $>40.0$ & $>40.0$ & $>40.0$ \\
\hline \multicolumn{7}{|c|}{ 1-7 days after discontinuation of biotin } \\
\hline $\mathrm{TSH}[\mu \mathrm{IU} / \mathrm{mL}]$ & 1.80 & 3.75 & 6.07 & 2.20 & 8.12 & 2.87 \\
\hline $\mathrm{fT}_{4}[\mathrm{ng} / \mathrm{dL}]$ & 1.58 & 1.70 & 1.16 & 1.13 & 1.84 & 1.91 \\
\hline $\mathrm{T}_{3}[\mathrm{ng} / \mathrm{dL}]$ & 2.0 & - & 1.8 & - & 1.8 & 2.3 \\
\hline TRAb [IU/L] & $<0.3$ & - & 0.7 & 1.0 & 0.4 & $<0.3$ \\
\hline
\end{tabular}

TSH — thyroid-stimulating hormone; fT4 — free thyroxine; T3 — triiodothyronine; TRAb — TSH receptor autoantibody 
monly they are papers presenting individual clinical cases. They refer to various age groups: from neonates to the elderly. The majority of them reported abnormal results of concentration of thyroid hormones (fT4, fT3) and TSH [17-25], but also of PTH, adrenocorticotropic hormone $(\mathrm{ACTH})$, prolactin, testosterone, cortisol, and oestradiol $[6,16,26]$. The number of those reports were so high that in November 2017 the American Food and Drug Administration (FDA) issued a warning indicating possible interference of biotin with immunochemical assays. Particularly disturbing was the fatal case of a patient with false low blood troponin (cardiomyocyte necrosis marker) levels in a test based on the SA/B system. The patient was using high doses of biotin. That case indicates possible serious consequences of false test results caused by the presence of exogenous biotin in a tested sample [27].

Arya et al. described a case of four neonates with suspected metabolic disease, who were administered biotin. Abnormal thyroid hormone levels were observed in all of them, with absence of any clinical symptoms suggesting thyrotoxicosis (the analyser used was from Roche Diagnostics). Biotin was discontinued in three of those neonates, following exclusion of the suspected metabolic disease. All results returned to normal. In the case of the one neonate who was further administered biotin, thyroid hormone levels proved to be within their reference ranges, when assays were completed using a different type of analyser (Centaur from Siemens) [9]. In a three-year-old girl with propionic acidaemia, the investigation of thyroid hormones was recommended as a part of further diagnostics. The $\mathrm{TSH}$ results were below the normal range, but levels of fT4 and fT3 were within their reference ranges (the analyser from Roche Diagnostics). The clinical symptoms observed in the patient did not indicate thyrotoxicosis. For that reason, repeated tests using a different analyser were recommended. In the obtained results the TSH level was normal, and levels of fT4 and fT3 were significantly increased (the analyser used was from Beckman Coulter). The patient was treated with $10 \mathrm{mg}$ of biotin four times a day, and differences in results of assays were because not all applied tests were based on the SA/B system (TSH assay, analyser from Beckman Coulter)[17]. In May 2018 a report was published describing a case of a 47 -year-old male with SM, who was administered biotin at the dose of $300 \mathrm{mg}$ /day. Investigations of his thyroid function indicated hyperthyroidism (significantly decreased TSH and increased fT4 and fT3 levels). Those results, combined with increased titres of antibodies against TPO (a-TPO) and the TSH receptor (TRAb), suggested Graves-Basedow's disease (G-B). Considering the absence of any clinical symptoms of hyperthyroidism, repeated assays were recommended two weeks after discontinuation of biotin supplementation. All results, except for TRAb, returned to normal [28]. Biotin interference of immunochemical tests caused a suspicion of G-B disease in two other patients [23, 29, 30], and additionally of hyperoestrogenism on one of them [6]. In mid-2018 a 48-year-old woman with hirsutism, increased body weight, and suspected thyroid disease was ordered additional hormonal investigations. Considering her increased testosterone and cortisol levels, and decreased ACTH and prolactin levels (analysers from Roche Diagnostics and OCD Vitros), imaging diagnostics (MRI and CT) was ordered for the patient. The obtained images did not confirm a suspicion of inactive adenoma and adrenal disease. Considering the increased testosterone level, testosterone-secreting ovarian cancer was suspected, and hysterectomy with oophorectomy was performed needlessly. The assay of free and total testosterone with the LC-MS/MS technique demonstrated that the results were normal. Following discontinuation of biotin supplementation at the dose of $5 \mathrm{mg} /$ day for two weeks, the majority of laboratory parameters, except for TSH, returned to normal. However, determination of TSH using a different analyser indicated that the results were within the reference range (TSH $1.1 \mathrm{mIU} / \mathrm{mL}$, analyser from Beckman Coulter), and clinically the patient was in euthyreosis [31]. Biotin interference was reported also for the determination of PTH $[16,26]$. False low PTH level was found in two patients: women aged 60 and 62 years using $1.5 \mathrm{mg}$ and $5 \mathrm{mg}$ biotin, respectively [26].

Table III presents results of hormonal assays for patients in whom the presence of interference caused by various doses of biotin was found (developed after Samarasinghe et al. [12]).

Due to their character, immunochemical tests based on the interaction between antibodies and antigens are susceptible to interference of antibodies demonstrating an affinity to components of the test. The procedure of this type of test may be affected by antibodies against streptavidin [32, 33], heterophilic antibodies interacting with biotin $[34,35]$, antibodies against murine IgG [36], antibodies against ruthenium [37], or antibodies against biotin [38].

\section{Conclusions}

False low or false high results of hormone assays resulting from biotin interference with immunochemical tests based on the SA/B system may lead to incorrect diagnosis and inappropriate treatment, exposure of a patient to long-term stress, and needless additional laboratory and imaging diagnostic procedures that increase the cost of treatment. Both physicians and 
Table III. Hormone levels in patients with confirmed interference resulting from the use of various doses of biotin

\begin{tabular}{|c|c|c|c|c|c|}
\hline $\mathbf{N}^{0}$ & Author (year) & Age / Sex & Biotin dose & $\begin{array}{c}\text { Changes in laboratory } \\
\text { tests }\end{array}$ & Immunochemistry analyser \\
\hline 1 & Koehler et al. (2018) & 47-year-old man & $300 \mathrm{mg} / \mathrm{d}$ & $\begin{array}{l}\downarrow T S H \text { TfT4 } \uparrow f T 3 \uparrow T P O A b \\
\text { 个TRAb }\end{array}$ & No data \\
\hline 2 & Stieglitz et al. (2018) & 48-year-old woman & $5 \mathrm{mg} / \mathrm{d}$ & $\begin{array}{l}\downarrow \downarrow T S H \downarrow A C T H \downarrow P R L \\
\uparrow T E S T O \uparrow C O R T\end{array}$ & $\begin{array}{l}\text { Roche Cobes e601 OCD Vitros } 5600 \\
\text { Beckman Coulter UniCel DxI } 800\end{array}$ \\
\hline 3 & Evans et al. (2018) & 15-month-old boy & $15-100 \mathrm{mg} / \mathrm{d}$ & $\leftrightarrow \mathrm{TSH} \uparrow \mathrm{fT} 4$ & Beckman Coulter DxI \\
\hline 4 & Arya et al. (2018) & 9-months-old girl & $2.5 \mathrm{mg} / \mathrm{kg} / \mathrm{d}$ & $\downarrow$ TSH $\uparrow f T 4 ~ \uparrow f T 3$ & Roche Diagnostics \\
\hline 5 & Arya et al. (2018) & 9-month-old girl & $2.5 \mathrm{mg} / \mathrm{kg} / \mathrm{d}$ & $\downarrow T S H$ 个fT4 个fT3 & Roche Diagnostics \\
\hline 6 & Arya et al. (2018) & Boy $<1$ month old & $4 \mathrm{mg} / \mathrm{kg} / \mathrm{d}$ & $\downarrow$ TSH $\uparrow f T 4 ~ \uparrow f T 3$ & Roche Diagnostics Siemens Centaur \\
\hline 7 & Arya et al. (2018) & Boy $<1$ month old & $5.2 \mathrm{mg} / \mathrm{kg} / \mathrm{d}$ & 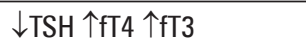 & Roche Diagnostics \\
\hline 8 & Cusini et al. (2017) & 69-year-old woman & $100 \mathrm{mg} / 3 \times \mathrm{d}$ & 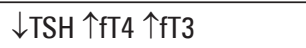 & Roche Diagnostics \\
\hline 9 & Willeman et al. (2017) & 39-year-old man & $50 \mu \mathrm{g} / \mathrm{d}$ & $\downarrow \mathrm{TSH} \leftrightarrow \mathrm{fT} 4 \leftrightarrow \mathrm{fT} 3$ & $\begin{array}{l}\text { Siemens Dimension Vista } 1500 \\
\text { Intelligent Lab System }\end{array}$ \\
\hline 10 & Sulaiman (2016) & 3 patients & $1-10 \mathrm{mg} / \mathrm{kg} / \mathrm{d}$ & $\begin{array}{l}\downarrow \mathrm{TSH} \uparrow \mathrm{fT} 4 \text { 个fT3 } \leftrightarrow \mathrm{TSH} \\
\leftrightarrow \mathrm{fT} 4 \leftrightarrow \mathrm{fT} 3\end{array}$ & $\begin{array}{l}\text { Roche Modular Cobas } 602 \text { Abbott } \\
\text { Architect I-2000 }\end{array}$ \\
\hline 11 & Minkovsky et al. (2016) & 74-year-old woman & $100 \mathrm{mg} / 3 \times \mathrm{d}$ & $\downarrow T S H$ 个fT4 $\uparrow f T 3$ & Roche Diagnostics \\
\hline 12 & Kummer et al. (2016) & 9-year-old girl & $10 \mathrm{mg} / \mathrm{kg} / \mathrm{d}$ & $\downarrow T S H$ 个fT4 $\uparrow T 3$ 个TRAb & Roche Diagnostics \\
\hline 13 & Kummer et al. (2016) & 2-year-old girl & $14 \mathrm{mg} / \mathrm{kg} / \mathrm{d}$ & $\downarrow T S H$ 个TT4 个TRAb & Roche Diagnostics \\
\hline 14 & Kummer et al. (2016) & 2-year-old boy & $15 \mathrm{mg} / \mathrm{kg} / \mathrm{d}$ & $\downarrow T S H$ 个fT4 $\uparrow T 3$ 个TRAb & Roche Diagnostics \\
\hline 15 & Kummer et al. (2016) & 5-month-old boy & $2 \mathrm{mg} / \mathrm{kg} / \mathrm{d}$ & $\downarrow T S H$ 个fT4 $\uparrow T 3$ 个TRAb & Roche Diagnostics \\
\hline 16 & Kummer et al. (2016) & 1-month-old boy & $7 \mathrm{mg} / \mathrm{kg} / \mathrm{d}$ & $\downarrow T S H$ 个fT4 个T3 个TRAb & Roche Diagnostics \\
\hline 17 & Kummer et al. (2016) & 1-month-old boy & $8 \mathrm{mg} / \mathrm{kg} / \mathrm{d}$ & $\downarrow T S H$ 个fT4 $\uparrow T R A b$ & Roche Diagnostics \\
\hline 18 & Batista et al. (2016) & 52-year-old woman & $10 \mathrm{mg} / \mathrm{d}$ & $\begin{array}{l}\downarrow \text { TSH } \leftrightarrow \text { fT4 } \leftrightarrow \text { fT3 } \\
\text { 个ESTRADIOL TRAb }+\end{array}$ & $\begin{array}{l}\text { OCD Vitros } 5600 \text { Roche E170/Cobas } \\
602 \text { Modular }\end{array}$ \\
\hline 19 & Elston et al. (2016) & 63-year-old woman & $100 \mathrm{mg} / 3 \times \mathrm{d}$ & $\begin{array}{l}\downarrow T S H \text { 个fT4 个fT3 个TRAb } \\
\leftrightarrow \text { TSH } \uparrow f T 4 \text { 个fT3 }\end{array}$ & $\begin{array}{l}\text { Roche Diagnostics Cobas } 6000 \\
\text { Beckman Coulter Dxl }\end{array}$ \\
\hline 20 & Barbesio (2016) & 55-year-old man & $100 \mathrm{mg} / 3 \times \mathrm{d}$ & $\downarrow T S H$ 个fT4 个fT3 个TRAb & Roche Diagnostics Elecsys \\
\hline 21 & Waghray et al. (2013) & 60-year-old woman & $1.5 \mathrm{mg} / \mathrm{d}$ & $\downarrow \mathrm{PTH}$ & $\begin{array}{l}\text { Siemens Advia Centaur Roche } \\
\text { Cobas E411 }\end{array}$ \\
\hline 22 & Waghray et al. (2013) & 62-year-old woman & $5 \mathrm{mg} / \mathrm{d}$ & $\downarrow \mathrm{PTH}$ & $\begin{array}{l}\text { Siemens Advia Centaur Roche } \\
\text { Cobas E411 }\end{array}$ \\
\hline 23 & Wijeratne (2012) & 1-week-old child & $30 \mathrm{mg} / \mathrm{d}$ & $\leftrightarrow \mathrm{TSH} \uparrow \mathrm{fT} 4$ 个fT3 & Beckman Coulter DxI \\
\hline 24 & Kwok et al. (2012) & 3-year-old girl & $10 \mathrm{mg} / 4 \times \mathrm{d}$ & $\begin{array}{l}\downarrow \mathrm{TSH} \leftrightarrow \mathrm{fT} 4 \leftrightarrow \mathrm{fT} 3 \\
\leftrightarrow \mathrm{TSH} \uparrow \mathrm{fT} 4 \text { 个fT3 }\end{array}$ & $\begin{array}{l}\text { Roche Cobas e601 Beckman } \\
\text { Coulter Access }\end{array}$ \\
\hline 25 & Meany et al. (2009) & 64-year-old woman & $10 \mathrm{mg} / \mathrm{d}$ & $\downarrow \mathrm{PTH}$ & Roche Elecsys 2010 \\
\hline 26 & Henry et al. (1996) & Newborn & $10 \mathrm{mg} / \mathrm{d}$ & $\downarrow \mathrm{TSH} \uparrow \mathrm{fT} 4$ & Boehringer Mannheim ES700 \\
\hline
\end{tabular}

TSH — thyroid-stimulating hormone; fT4 — free thyroxine; fT3 — free triiodothyronine; TPOAb — anti-thyroid peroxidase autoantibody; TRAb — TSH receptor autoantibody; ACTH — adrenocorticotropic hormone; PRL — prolactin; TESTO — testosterone; CORT — cortisol; PTH — parathyroid hormone

laboratory diagnosticians should cooperate for elimination of that problem.

Actions to be taken by a physician in order to limit the biotin interference:

- getting information about any biotin-containing dietary supplements used by a patient when gathering the medical history (dose, duration of use);

- contacting a laboratory to determine if a particular diagnostic test is susceptible to biotin interference and to what extent;
- if the medical history indicates the use of biotin-containing formulas, laboratory investigations should be performed some time after their discontinuation (depending on time and dose, the period should be from 1 (for low doses) to 3-7 days (higher doses), but individual differences influencing the correlation between biotin supplementation and laboratory investigations have to be considered as well;

- in the case of discrepancy between laboratory results and the clinical presentation, repeating the test us- 


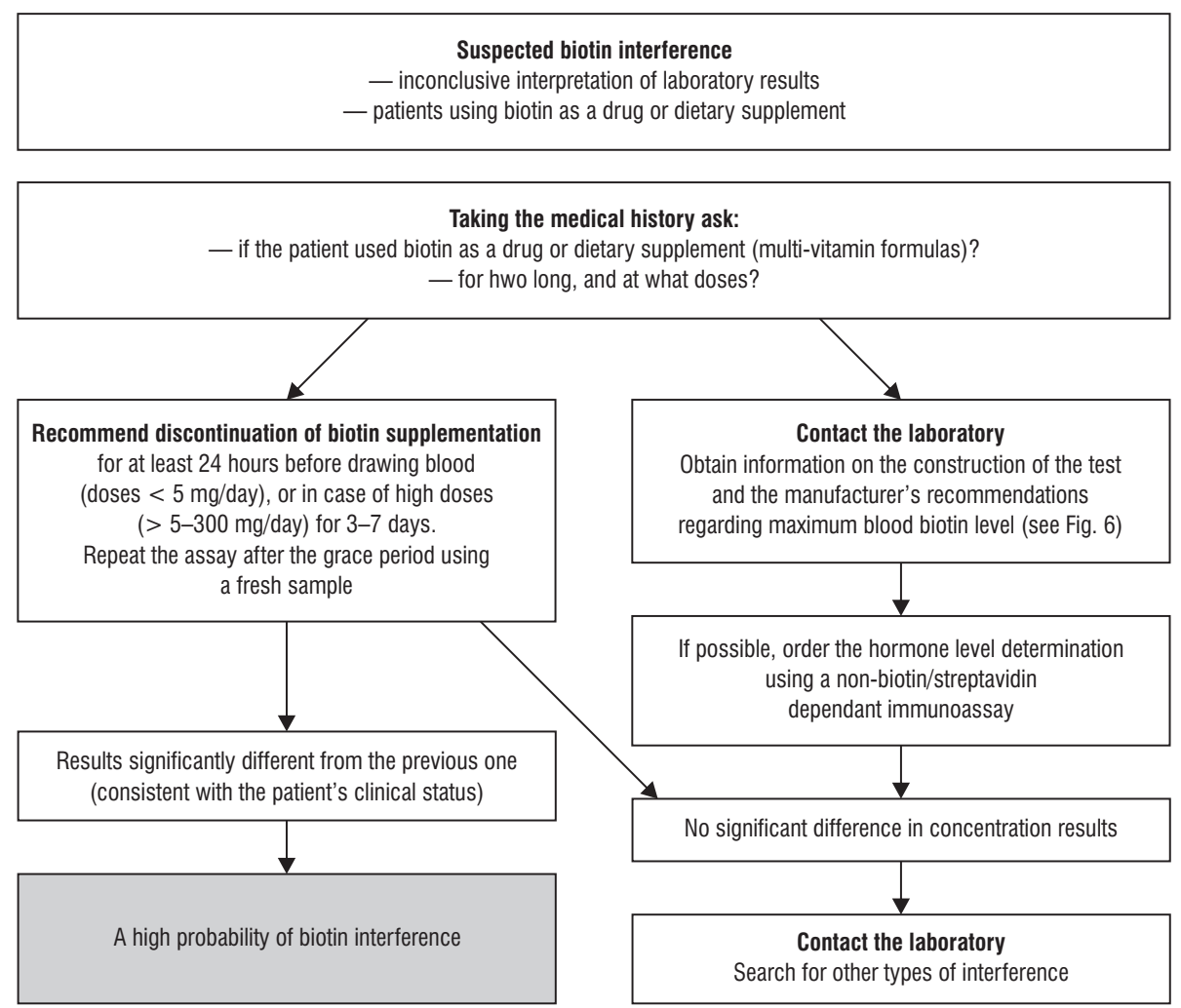

Figure 5. Algorithm of actions in case of suspected biotin interference, to be used by a clinician

ing an immunochemical test from a different manufacturer, containing no streptavidin (avidin)-biotin system, is recommended. In this case a physician should contact the laboratory in order to determine a reference centre (laboratory) that does not use tests based on the SA/B system;

- if the result of a test (repeated with another test) is still discordant with the clinical presentation, another cause of interference to immunochemical assays has to be considered - repeated contact with the laboratory is recommended.

The Figure 5 presents the algorithm of actions to be used by a clinician in the case of suspected biotin interference

Actions to be taken by a medical diagnostic laboratory in order to limit the biotin interference:

- biotin level determination in a patient's sample, before the assay itself, is not possible, because no fully automatic tests for determination of biotin level are currently available for routine laboratory operation;

- a method of removing excess of exogenous biotin from a tested sample has been developed recently $[8,40]$. The method involves preliminary addition of an appropriate amount of micro-molecules coated with streptavidin (obtained from used reagents) to a sample of serum collected from a patient. The mixture is then incubated (with shaking) for 45 minutes at room temperature. The selected laboratory parameter is determined in the supernatant obtained by centrifugation $[8,39,40]$. Although the whole procedure is not expensive (reagents to be discarded are used), and the time of the procedure is approx. $1 \mathrm{~h}$, the method is hard to adapt to routine operation of a laboratory. Another method used for removal of biotin from a test sample may be chromatography of affinity. Neither of these methods is currently commonly used, and they both require a certain level of expertise in identification of various types of interference;

- it is recommended that a laboratory develop its own algorithm of actions to be taken in the case of suspected biotin interference - use of tests containing no SA/B system, access to manual isotope-based methods, chromatographic methods (particularly LC/MS/MS), or — most commonly - cooperation with a laboratory using methods (automatic, manual) that are not susceptible to biotin interference;

- a search for other types of interference (e.g. presence of antibodies against streptavidin, heterophilic antibodies, hormone macro-molecules, etc.).

Figure 6 presents the algorithm of actions in case of suspected biotin interference, to be used by a laboratory diagnostician. 


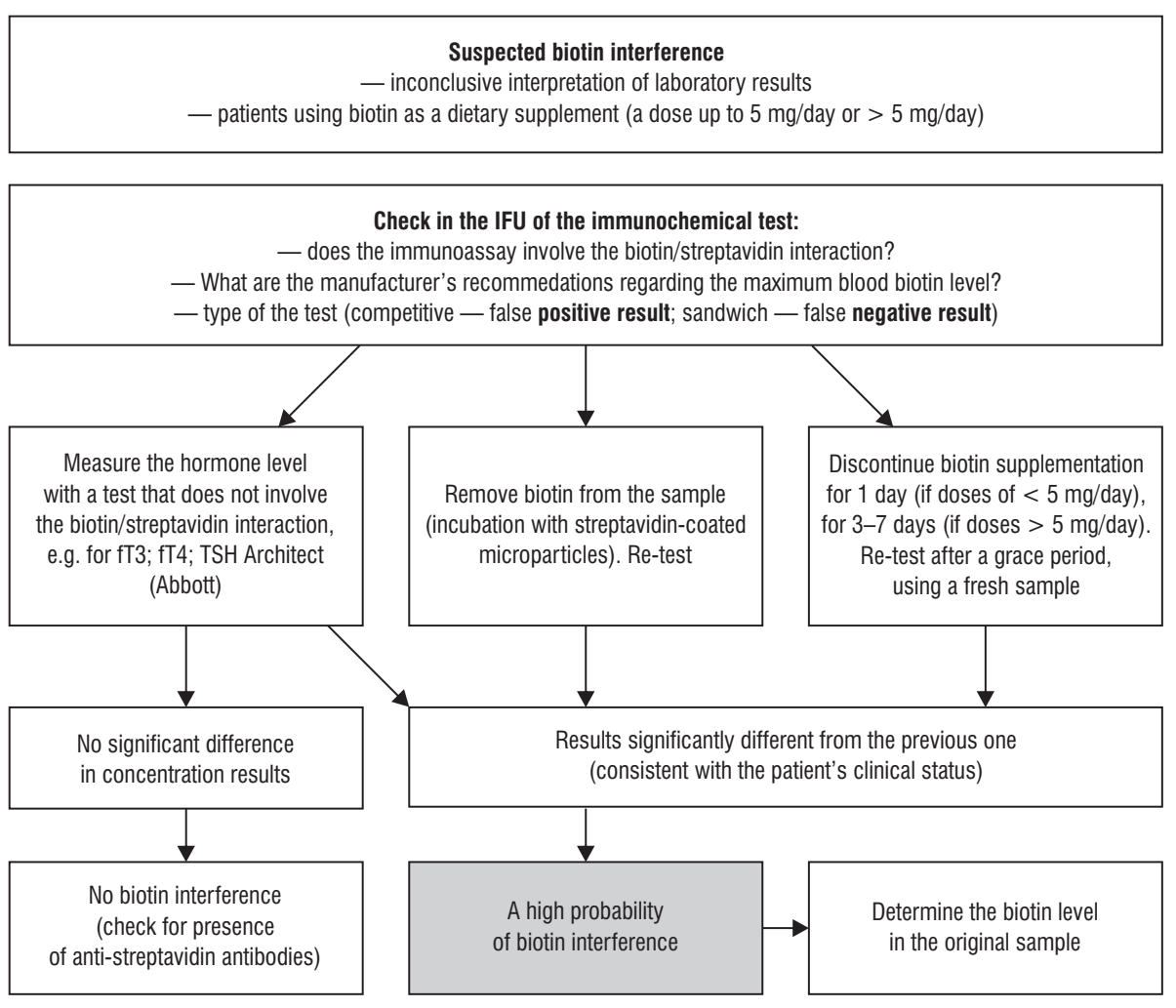

Figure 6. Algorithm of actions in case of suspected biotin interference, to be used by a laboratory diagnostician

\section{Author contributions}

M.O. and Z.B. contributed equally to this work.

\section{References}

1. Najwyższa Izba Kontroli. Diagnostyka laboratoryjna w Polsce [panel eskpertów. https://www.nik.gov.pl/aktualnosci/organizacja-i-finansowanie-diagnostyki-laboratoryjnej-panel-ekspertow.html.

2. Diamandis EP, Christopoulos TK. The biotin-(strept)avidin system: principles and applications in biotechnology. Clin Chem. 1991; 37(5): 625-636, indexed in Pubmed: 2032315.

3. Mattman A, Potter M. Approach to the interpretation of unexpected laboratory results arising in the care of patients with inborn errors of metabolism (IEM). Rev Endocr Metab Disord. 2018; 19(1): 5-12, doi: 10.1007/s11154-018-9453-4, indexed in Pubmed: 30032338.

4. Piketty ML, Polak M, Flechtner I, et al. False biochemical diagnosis of hyperthyroidism in streptavidin-biotin-based immunoassays: the problem of biotin intake and related interferences. Clin Chem Lab Med. 2017; 55(6): 780-788, doi: 10.1515/cclm-2016-0606, indexed in Pubmed: 27732554 .

5. Zempleni J, Wijeratne SSK, Hassan YI. Biotin. Biofactors. 2009; 35(1): 36-46, doi: 10.1002/biof.8, indexed in Pubmed: 19319844.

6. Batista MC, Ferreira CES, Faulhaber ACL, et al. Biotin interference in immunoassays mimicking subclinical Graves' disease and hyperestrogenism: a case series. Clin Chem Lab Med. 2017; 55(6): e99-e9e103, doi: 10.1515/cclm-2016-0628, indexed in Pubmed: 27718482

7. Gifford JL, Sadrzadeh S, Naugler C. Biotin interference: Underrecognized patient safety risk in laboratory testing. Can Fam Physician. 2018 ; 64(5): 370, doi: 10.1515/cclm-2016-1183, indexed in Pubmed: 29760259.

8. Piketty ML, Prie D, Sedel F, et al. High-dose biotin therapy leading to false biochemical endocrine profiles: validation of a simple method to overcome biotin interference. Clin Chem Lab Med. 2017; 55(6): 817-825, doi: 10.1515/cclm-2016-1183, indexed in Pubmed: 28222020.

9. Arya VB, Ajzensztejn M, Appleby G, et al. High-dose biotin in infants mimics biochemical hyperthyroidism with some commercial assays. Clin Endocrinol (Oxf). 2018; 88(3): 507-510, doi: 10.1111/cen.13547, indexed in Pubmed: 29314108.

10. Sedel F, Papeix C, Bellanger A, et al. High doses of biotin in chronic progressive multiple sclerosis: a pilot study. Mult Scler Relat Disord. 2015; 4(2): 159-169, doi: 10.1016/j.msard.2015.01.005, indexed in Pubmed: 25787192
11. Li D, Radulescu A, Shrestha RT, et al. Association of Biotin Ingestion With Performance of Hormone and Nonhormone Assays in Healthy Adults. JAMA. 2017; 318(12): 1150-1160, doi: 10.1001/jama.2017.13705, indexed in Pubmed: 28973622.

12. Samarasinghe S, Meah F, Singh V, et al. Biotin Interference with Routine Clinical Immunoassays: Understand the Causes and Mitigate the Risks. Endocr Pract. 2017; 23(8): 989-998, doi: 10.4158/EP171761.RA, indexed in Pubmed: 28534685.

13. Holmes EW, Samarasinghe $S$, Emanuele MA, et al. Biotin Interference in Clinical Immunoassays: A Cause for Concern. Arch Pathol Lab Med. 2017; 141(11): 1459-1460, doi: 10.5858/arpa.2017-0107-LE, indexed in Pubmed: 29072950.

14. Trambas C, Lu Z, Yen T, et al. Characterization of the scope and magnitude of biotin interference in susceptible Roche Elecsys competitive and sandwich immunoassays. Ann Clin Biochem. 2018; 55(2): 205-215, doi: 10.1177/0004563217701777, indexed in Pubmed: 28875734

15. Willeman T, Casez O, Faure P, et al. Evaluation of biotin interference on immunoassays: new data for troponin I, digoxin, NT-Pro-BNP, and progesterone. Clin Chem Lab Med. 2017; 55(10): e226-e229, doi: 10.1515/cclm-2016-0980, indexed in Pubmed: 28222017.

16. Meany DL, Beur SMJ, Bill MJ, et al. A case of renal osteodystrophy with unexpected serum intact parathyroid hormone concentrations. Clinical Chemistry. 2009; 55(9): 1737-1739, doi: 10.1373/clinchem.2008.121921.

17. Kwok JSS, Chan IHS, Chan MHM. Biotin interference on TSH and free thyroid hormone measurement. Pathology. 2012; 44(3): 278-280, doi: 10.1097/PAT.0b013e3283514002, indexed in Pubmed: 22437752.

18. Wijeratne NG, Doery JCG, Lu ZX. Positive and negative interference in immunoassays following biotin ingestion: a pharmacokinetic study. Pathology. 2012; 44(7): 674-675, doi: 10.1097/PAT.0b013e32835a3c17, indexed in Pubmed: 23089740.

19. Minkovsky A, Lee MN, Dowlatshahi M, et al. High-dose biotin treatment for secondary progressive multiple sclerosis may interfere with thyroid assays. AACE Clin Case Rep. 2016; 2(4): e370-e373, doi: 10.4158/EP161261. CR, indexed in Pubmed: 27917400.

20. Kummer S, Hermsen D, Distelmaier F. Biotin Treatment Mimicking Graves' Disease. N Engl J Med. 2016; 375(7): 704-706, doi: 10.1056/NEJMc1602096, indexed in Pubmed: 27532849.

21. Henry JG, Sobki S, Arafat N. Interference by biotin therapy on measurement of TSH and FT4 by enzyme immunoassay on Boehringer Mannheim ES700 analyser. Ann Clin Biochem. 1996; 33(Pt 2): 162-163, doi: 10.1177/000456329603300214, indexed in Pubmed: 8729729.

22. Willeman T, Casez O, Faure P. Biotin in multiple sclerosis and false biological hyperthyroidism: Mind the interference. Rev Neurol (Paris). 
2017; 173(3): 173-174, doi: 10.1016/j.neurol.2017.02.009, indexed in Pubmed: 28302321.

23. Elston MS, Sehgal S, Du Toit S, et al. Factitious Graves' disease due to biotin immunoassay interference - a case and review of the literature. J Clin Endocrinol Metab. 2016; 101(9): 3251-3255, doi: 10.1210/jc.2016-1971, indexed in Pubmed: 27362288.

24. Sulaiman RA. Biotin treatment causing erroneous immunoassay results: A word of caution for clinicians. Drug Discov Ther. 2016; 10(6): 338-339, doi: 10.5582/ddt.2016.01074, indexed in Pubmed: 28090070.

25. Evans N, Yates J, Tobin J, et al. Immunoassay interference secondary to therapeutic high-dose biotin: A paediatric case report. J Paediatr Child Health. 2018; 54(5): 572-575, doi: 10.1111/jpc.13857, indexed in Pubmed: 29405469.

26. Waghray A, Milas M, Nyalakonda K, et al. Falsely low parathyroid hormone secondary to biotin interference: a case series. Endocr Pract. 2013; 19(3): 451-455, doi: 10.4158/EP12158.OR, indexed in Pubmed: 23337137.

27. US Food and Drug Administration. The FDA warns that biotin may interfere with lab tests: FDA safety communication. https://www.fda. gov/medicaldevices/safety/alertsandnotices/ucm586505.htm.

28. Koehler VF, Mann U, Nassour A, et al. Fake news? Biotin interference in thyroid immunoassays. Clin Chim Acta. 2018; 484: 320-322, doi: 10.1016/j. cca.2018.05.053, indexed in Pubmed: 29856977.

29. Cusini C, Sassi L, De Paola G, et al. Apparent biochemical thyrotoxicosis due to assay interference by high-dose biotin given for multiple sclerosis. Endocrinol Invest. 2017; 40(8): 889-890, doi: 10.1007/s40618-017-0678-y, indexed in Pubmed: 28478548

30. Barbesino G. Misdiagnosis of Graves' disease with apparent severe hyperthyroidism in a patient taking biotin megadoses. Thyroid. 2016; 26(6): 860-863, doi: 10.1089/thy.2015.0664, indexed in Pubmed: 27043844.

31. Stieglitz HM, Korpi-Steiner N, Katzman B, et al. Suspected Testosterone-Producing Tumor in a Patient Taking Biotin Supplements. J En- docr Soc. 2018; 2(6): 563-569, doi: 10.1210/js.2018-00069, indexed in Pubmed: 29942920.

32. Lam L, Bagg W, Smith G, et al. Apparent hyperthyroidism caused by biotin-like interference from IgM anti-atreptavidin antibodies. Thyroid. 2018; 28(8): 1063-1067, doi: 10.1089/thy.2017.0673, indexed in Pubmed: 29808739.

33. Rulander NJ, Cardamone $\mathrm{D}$, Senior $\mathrm{M}$, et al. Interference from anti-streptavidin antibody. Arch Pathol Lab Med. 2013; 137(8): 1141-1146, doi: 10.5858/arpa.2012-0270-CR, indexed in Pubmed: 23899071.

34. Brugts MP, Luermans JG, Lentjes EG, et al. Heterophilic antibodies may be a cause of falsely low total IGF1 levels. Eur J Endocrinol. 2009. 161(4): 561-565, doi: 10.1530/EJE-09-0316, indexed in Pubmed: 19608715.

35. Vos MJ, Rondeel JMM, Mijnhout GS, et al. Immunoassay interference caused by heterophilic antibodies interacting with biotin. Clin Chem Lab Med. 2017; 55(6): e122-e126, doi: 10.1515/cclm-2016-0786, indexed in Pubmed: 27754962.

36. Kricka LJ. Human anti-animal antibody interferences in immunologica assays. Clin Chem. 1999; 45(7): 942-956, indexed in Pubmed: 10388468.

37. Heijboer AC, Ijzerman RG, Bouman AA, et al. Two cases of antiruthenium antibody interference in Modular free thyroxine assay. Ann Clin Biochem. 2009; 46(Pt 3): 263-264, doi: 10.1258/acb.2009.008258, indexed in Pubmed: 19261677.

38. Chen T, Hedman L, Mattila PS, et al. Biotin IgM antibodies in human blood: a previously unknown factor eliciting false results in biotinylation-based immunoassays. PLoS One. 2012; 7(8): e42376, doi: 10.1371/journal.pone.0042376, indexed in Pubmed: 22879954.

39. Lam L, Kyle CV. A simple method to detect biotin interference on immunoassays. Clin Chem Lab Med. 2017; 55(6): e104-e106, doi: 10.1515/cclm-2017-0059, indexed in Pubmed: 28306526.

40. Trambas C, Lu Z, Yen T, et al. Depletion of biotin using streptavidin-coated microparticles: a validated solution to the problem of biotin interference in streptavidin-biotin immunoassays. Ann Clin Biochem. 2018; 55(2): 216-226, doi: 10.1177/0004563217707783, indexed in Pubmed: 28406314. 


\title{
Wpływ interferencji biotyny na wyniki oznaczeń stężenia hormonów we krwi
}

\author{
Magdalena Ostrowska', Zbigniew Bartoszewicz², Tomasz Bednarczuk², Klaudia Walczak², \\ Wojciech Zgliczyński ${ }^{1}$, Piotr Glinicki ${ }^{1}$ \\ ${ }^{1}$ Klinika Endokrynologii, Centrum Medyczne Ksztatcenia Podyplomowego, Warszawa, Polska \\ ${ }^{2}$ Katedra i Klinika Chorób Wewnętrznych i Endokrynologii, Warszawski Uniwersytet Medyczny, Warszawa, Polska
}

Artykuł jest tłumaczeniem pracy: Magdalena Ostrowska, Zbigniew Bartoszewicz, Tomasz Bednarczuk, Klaudia Walczak, Wojciech Zgliczyński, Piotr Glinicki. The effect of biotin interference on the results of blood hormone assays. Endokrynol Pol 2019; 70 (1): 102-111.

Należy cytować wersję pierwotną.

Piśmiennictwo dostępne w wersji pierwotnej na stronach 110-111.

\begin{abstract}
Streszczenie
Około 70\% decyzji medycznych podejmowanych jest na podstawie wyników badań laboratoryjnych. W rutynowej diagnostyce laboratoryjnej zaburzeń endokrynologicznych stosuje się głównie metody immunochemiczne. Pewnym ograniczeniem tych metod jest podatność na zakłócenie reakcji immunochemicznej przez różnego typu interferencje. Przyczyną interferencji może być obecność w surowicy pacjenta przeciwciał autologicznych, przeciwciał heterofilnych, paraprotein, reakcje krzyżowe z podobnymi związkami, hemoliza, znaczna lipemia lub hiperbilirubinemia. W ostatnich kilku latach pojawiły się doniesienia o istotnych zafałszowaniach wyników badań spowodowanych przez biotynę. Biotyna jest rozpuszczalną w wodzie witaminą z grupy B. Występuje w popularnych suplementach diety, pojedynczo lub jako składnik preparatów multiwitaminowych. Reklamowana jest jako środek na problemy z wypadaniem i łamliwością włosów i paznokci. Biotyna ze względu na mały rozmiar cząsteczki oraz bardzo silne powinowactwo do streptawidyny znajduje zastosowanie w wielu testach immunochemicznych. Metody analityczne wykorzystujące układ streptawidyna (awidyna)-biotyna — ze względu na mocne, stabilne i specyficzne połączenie streptawidyny z biotyną — są bardziej czułe i umożliwiają oznaczenie bardzo niewielkich stężeń badanej substancji w materiale biologicznym. Obecność egzogennej biotyny w próbce może być przyczyną interferencji w przypadku testów wykorzystujących układ streptawidyna (awidyna)-biotyna. To, czy biotyna będzie interferowała w oznaczeniach testów immunochemicznych, zależy od kilku czynników: konstrukcji testu immunochemicznego, wielkości dawki, jaką przyjmuje pacjent, stężenia biotyny w badanej próbce, a przede wszystkim od czasu, jaki upłynie od przyjęcia ostatniej dawki do pobrania materiału do badań laboratoryjnych. W prezentowanej pracy przedstawiono praktyczne zalecenia i algorytm postępowania w przypadku podejrzenia interferencji biotyny w oznaczeniach immunochemicznych dla lekarza klinicysty i diagnosty laboratoryjnego. (Endokrynol Pol 2019; 70 (1): 112-121)

Słowa kluczowe: biotyna; interferencja; immunochemia; suplementy diety; przeciwciała anty-streptowidynowe
\end{abstract}

\section{Wstęp}

Około 70\% decyzji medycznych podejmowanych jest na podstawie wyników badań laboratoryjnych. Dokładny i wiarygodny wynik badania laboratoryjnego pozwala lekarzowi na postawienie odpowiedniej diagnozy i wybór właściwego sposobu leczenia. W rutynowej diagnostyce laboratoryjnej zaburzeń endokrynologicznych mają zastosowanie głównie metody immunochemiczne. Stosuje się je powszechnie ze względu na ich zalety, takie jak: dużą czułość, precyzję, specyficzność, możliwość bezpośredniego oznaczenia stężenia wybranego parametru w surowicy, osoczu lub innym materiale biologicznym oraz relatywnie krótki czas oczekiwania na wynik badania [2]. Ze względu na ogromny postęp technologiczny większość $\mathrm{z}$ tych technik jest w pełni zautomatyzowana i pozwala na oznaczanie szerokiego spektrum parametrów laboratoryjnych, takich jak: hormony, przeciwciała, markery nowotworowe, markery uszkodzenia narządów i/lub ich dysfunkcji, markery zakażeń wirusami, markery stanów zapalnych i martwicy tkanek oraz niektóre leki i witaminy. Około 15-20\% oznaczeń immunochemicznych wykonuje się $\mathrm{z}$ zastosowaniem metod izotopowych: metody radioimmunlogicznej (RIA, radioimmunological assay) $\mathrm{i}$ immunoradiometrycznej (IRMA, immunoradiometric assay). Znacząca większość oznaczeń immunochemicznych stosowanych w diagnostyce klinicznej bazuje na licznej grupie metod nieizotopowych, np. metodzie immunoenzymatycznej (ELISA, immunoenzymatic method), 
immunochemiluminesencyjnej (CLIA, immunochemiluminescence method), immunoelektrochemiluminescencyjnej (ECLIA, immunoelectrochemiluminescence method) i innych. Pewnym ograniczeniem tych metod jest podatność na zakłócenie reakcji immunochemicznej przez różnego typu interferencje. Przyczyną takich interferencji może być obecność $\mathrm{w}$ surowicy pacjenta przeciwciał autologicznych i tworzenie się in vivo makrocząsteczek, obecność przeciwciał heterofilnych skierowanych przeciwko zwierzęcym IgG (HAMA, human anit-mouse antibody albo HAAA, human anti-animal antibody), rekcje krzyżowe oraz takie powszechnie znane czynniki, jak: hemoliza, znacząca lipemia albo hiperbilirubinemia. $W$ ostatnich kilku latach zaczęły ukazywać się publikacje na temat interferencji spowodowanych biotyną, która była przyczyną fałszywie zawyżonych lub fałszywie zaniżonych wyników badań $\mathrm{w}$ testach wykorzystujących układ streptawidyna (awidyna)-biotyna (SA/B) $[3,4]$.

\section{Kiedy można podejrzewać wystąpienie interferencji biotyny w oznaczeniach immunochemicznych?}

Interferencje biotyny mogą występować $\mathrm{w}$ rożnych testach immunochemicznych (zarówno manualnych, jak i w metodach zautomatyzowanych) wykorzystujących w swojej konstrukcji układ streptawidyna (awidyna)-biotyna.

Wiązanie streptawidyna (awidyna)-biotyna jest jednym z najsilniejszych, niekowalencyjnych połączeń. Jest odporne na zmiany $\mathrm{pH}$, wielokrotne płukanie, czynniki chalotropowe i ekstremalne warunki reakcji (np. temperaturę). Ze względu na stabilność i wysoką czułość pozwalającą na oznaczenie nawet niewielkich stężeń badanego analitu (ng/ml, pg/ml) w materiale biologicznym metody analityczne powszechnie wykorzystują układ streptawidyna (awidyna)-biotyna. Ze względu na małe rozmiary cząsteczki wprowadzenie biotyny nie zmienia właściwości wielu związków, takich jak np. białka, hormony czy przeciwciała używane $w$ testach immunochemicznych, a sama biotynylacja nie nastręcza trudności metodycznych. Awidyna - zasadowe białko obecne w białku jaja kurzego oraz jej nieglikozylowany wariant - streptawidyna wytwarzana przez szczep Streptomyces avidini — są łatwe do pozyskania.

Interferencje biotyny dotyczą pacjentów z wysokim stężeniem biotyny we krwi na skutek jej stosowania jako suplementu diety lub u pacjentów leczonych wysokimi dawkami biotyny.

\section{Biotyna}

Biotyna (witamina H, B7, B8) jest rozpuszczalną w wodzie witaminą z grupy B. Może być syntetyzowana przez florę bakteryjną jelit, w związku z czym do jej niedoborów dochodzi rzadko, najczęściej w skutek stosowania szerokiego spektrum antybiotyków. Biotyna jest człowiekowi niezbędna do życia. Bierze udział jako koenzym kilku różnych enzymów w wielu szlakach metabolicznych. Jest ważnym koenzymem karboksylaz zaangażowanych $\mathrm{w}$ proces glukoneogenezy, syntezę kwasów nukleinowych oraz kwasów tłuszczowych, cykl Krebsa, czy degradację leucyny. Egzogenna biotyna jest szybko wchłaniana przez błonę śluzową jelit i wydalana głównie z moczem $\mathrm{w}$ postaci niezmienionej lub $\mathrm{w}$ postaci metabolitów, takich jak: bisnorbiotyna, sulfon biotyny, bisnorbiotyno-metylo-keton i inne [5]. Jej okres półtrwania we krwi wynosi około 110 min [6]. W diecie występuje m.in. w takich produktach, jak: wieprzowina, wątroba, żółtko jaja, ziarno soi, migdały czy warzywa liściaste. Dzienne zapotrzebowanie biotyny $\mathrm{u}$ dzieci zwiększa się wraz z wiekiem, natomiast dla osoby dorosłej wynosi 30-75 $\mu \mathrm{g}$ [7]. Biotyna występuje w popularnych suplementach diety, pojedynczo lub jako składnik preparatów multiwitaminowych. Jest ona reklamowana jako środek przeciwdziałający wypadaniu i łamliwości włosów i paznokci. W Polsce najpopularniejsze suplementy diety zawierają od $0,3 \mathrm{mg}$ do $10 \mathrm{mg}$ biotyny, co wielokrotnie (około 6-200 razy) przekracza jej średnie, dzienne zapotrzebowanie. Osoby stosujące wysokie dawki biotyny są szczególnie narażone na ten typ interferencji, tym bardziej, że biotynę można kupić w dowolnej ilości, a ze względu na jej niezwykle niską toksyczność istnieje bardzo niewielkie ryzyko jej przedawkowania.

Drugą grupę zagrożoną interferencją biotyny stanowią pacjenci leczeni wysokimi dawkami biotyny (5-300 mg/dzień) w terapii wrodzonych chorób metabolicznych: niedoborze biotynidazy, niedoborze transportera-2 tiaminy, niedoborze syntetazy holokarboksylazowej [8]. W większych dawkach biotynę stosuje się u noworodków i niemowląt, zwłaszcza przy podejrzeniu choroby metabolicznej [9] oraz u osób dorosłych ze stwardnieniem rozsianym i innymi chorobami demielinizacyjnymi [10]. Stosowanie biotyny w leczeniu niektórych chorób jest kwestionowane. Na skutek niewielkiego efektu terapeutycznego część leków na bazie biotyny wycofano z handlu, np. Medday Pharmaceuticals wycofało w Europie lek Qizenday stosowany $\mathrm{w}$ leczeniu postępującego stwardnienia rozsianego. Problem interferencji biotyny związany $\mathrm{z}$ leczeniem tymi preparatami praktycznie w Polsce nie występuje, ponieważ nie są zarejestrowane procedury medyczne dopuszczające jej stosowanie w wysokich dawkach jako leku. Jedynym zarejestrowanym lekiem jest Biotebal (Biotinum) z rekomendowanymi dawkami do $5 \mathrm{mg}$ na dobę. 


\section{Mechanizm interferencji biotyny w oznaczeniach immunochemicznych}

Obecność egzogennej biotyny w badanej próbce może być przyczyną interferencji w przypadku testów wykorzystujących układ SA/B. Pierwsze doniesienia o tym typie interferencji pojawily się w 1996 roku. Jednak dopiero w ostatnich kilku latach temat ten wzbudził większe zainteresowanie. Wiąże się to z coraz częściej wykrywaną niezgodnością wyników oznaczeń hormonalnych z obrazem klinicznym, co można potencjalnie wynikać z powszechnego stosowania suplementów diety zawierających biotynę.

Metody immunochemiczne opierają się na swoistej reakcji między epitopem (3-8 aminokwasów) na powierzchni antygenu a odpowiednim miejscem wiązania na cząsteczce przeciwciała. Przeciwciała stosowane $\mathrm{w}$ teście rozpoznają ściśle określoną strukturę chemiczną epitopu, a nie aktywność biologiczną substancji badanej. Stosowanie różnego rodzaju systemów detekcji (znaczników) pozwala śledzić reakcję immunologiczną oraz oznaczyć ilościowo stężenie lub miano badanej substancji. Wyróżnia się dwa główne rodzaje metod stosowane $\mathrm{w}$ rutynowych testach immunochemicznych. Metoda niekompetencyjna wykorzystuje dwa przeciwciała: wychwytujące i detekcyjne, które rozpoznają dwie różne determinanty antygenu. Powstaje kompleks przeciwciało wychwytujące-antygen-przeciwciało detekcyjne. Taki układ testu zwiększa czułość i specyficzność oznaczenia. Określany jest jako test typu sandwich (,kanapkowy”). Drugi typ reakcji wykorzystuje jako czynnik detekcyjny znakowany antygen lub jego analog, który konkuruje z badanym antygenem (nieznakowanym) o miejsca wiązania na cząsteczkach przeciwciała. Jest to metoda kompetycyjna. Powstają kompleksy antygen znakowany-przeciwciało oraz antygen badany-przeciwciało. Reakcje immunochemiczne mogą zachodzić w fazie ciekłej (typ reakcji homogenny) lub na fazie stałej (najczęściej obecnie stosowany), np. w probówce, na płytce czy z zastosowaniem mikrocząsteczek paramagnetycznych (typ reakcji heterogenny).

Egzogenna biotyna w teście „kanapkowym” (niekompetycyjnym) łączy się z opłaszczonymi streptawidyną mikrocząsteczkami fazy stałej, uniemożliwiając przyłączenie się do nich kompleksu przeciwciało biotynylowane-analit-przeciwciało znakowane. Powoduje to zmniejszenie intensywności mierzonego sygnału znacznika, a w konsekwencji prowadzi do otrzymania wyniku fałszywie zaniżonego, ponieważ w metodach niekompetycyjnych zależność sygnału od stężenia jest wprost proporcjonalna do stężenia badanego analitu. W metodzie kompetycyjnej nadmiar egzogennej biotyny również wiąże się z opłaszczonymi streptawidyną mikrocząsteczkami fazy stałej, blokując możliwość przyłączenia się do nich kompleksów zarówno przeciwciało biotynylowane-analit badany, jak i przeciwciało biotynylowane-analit znakowany. Podobnie jak w teście "kanapkowym" skutkuje to zmniejszeniem intensywności mierzonego sygnału, lecz w tym przypadku uzyskany wynik będzie fałszywie zawyżony, ponieważ liczba powstałych kompleksów związanych na fazie stałej jest odwrotnie proporcjonalna do stężenia badanego analitu. Na rycinach 1-4 przedstawiono schematy wyjaśniające mechanizmy reakcji immunochemicznych (metoda kompetycyjna oraz typu „kanapkowego") oraz
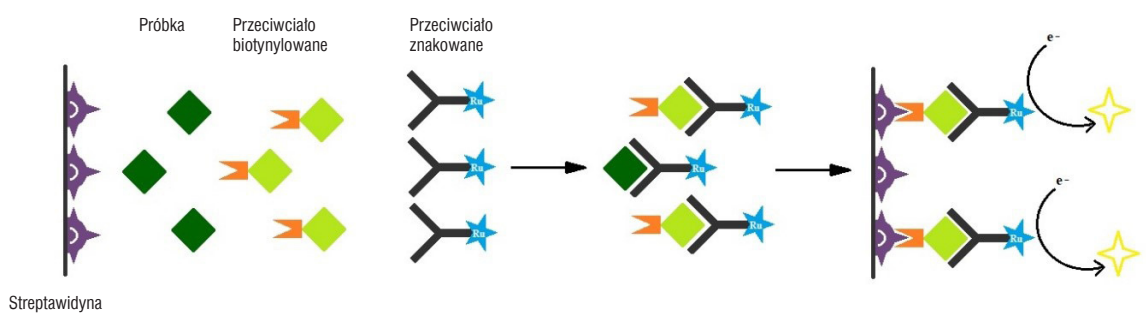

Rycina 1. Schemat metody kompetycyjnej

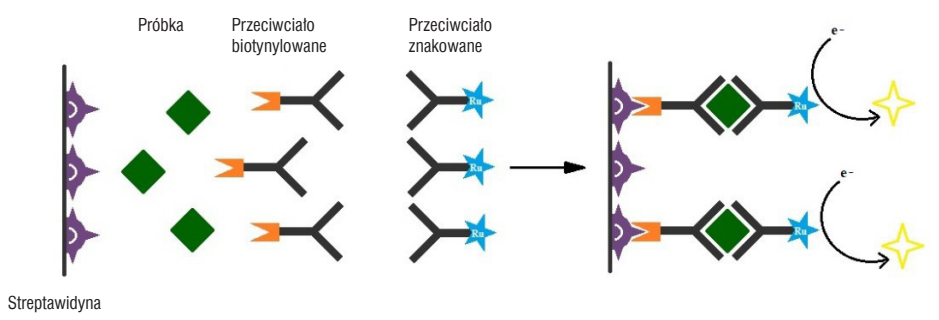

Rycina 2. Schemat metody niekompetycyjnej 


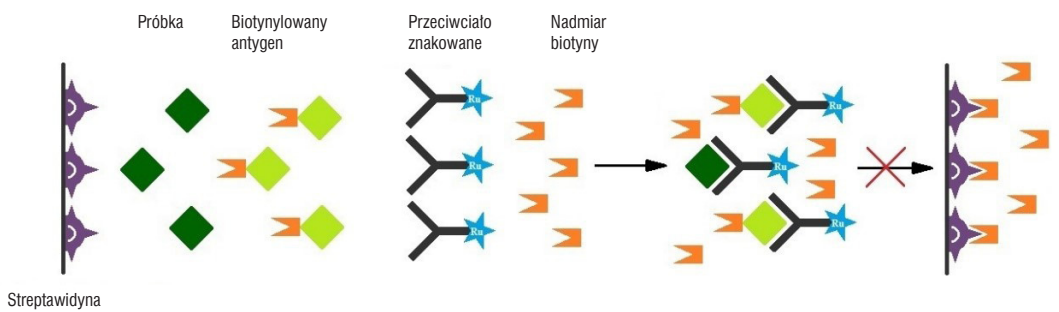

Rycina 3. Test kompetycyjny — wysokie stężenie biotyny

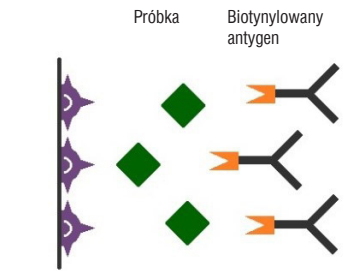

Streptawidyna
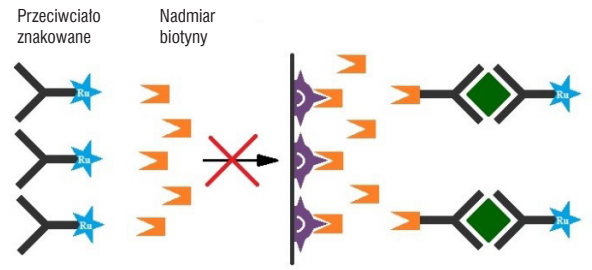

Rycina 4. Test niekompetycyjny — wysokie stężenie biotyny

mechanizm interferencji z wysokim stężeniem biotyny w obu metodach [11].

Testy niekompetycyjne (typ „kanapkowy”) służą do oznaczania stężenia dużych cząsteczek hormonów, takich jak: hormon tyreotropowy (TSH, thyroid-stimulating hormone), hormon lutenizujący ( $\mathrm{LH}$, luteinizing hormone), hormon folikulotropowy (FSH, follicle-stimulating hormone), gonadotropina kosmówkowa (hCG, human chorionic gonadotropin), parathormon (PTH, parathyroid hormone), insulinopodobny czynnik wzrostu (IGF-1, insulin-like growth factor), insulina, tyreoglobulina, C-peptyd. W tym typie testu podatnego na działanie biotyny (zawierającego układ SA/B) obserwuje się fałszywie ujemne (zaniżone) wyniki stężenia oznaczanych hormonów.

Testy kompetycyjne służą do oznaczania stężenia/miana małych cząsteczek hormonów i przeciwciał: tyroksyny (T4/fT4), trójjodotyroniny (T3/fT3), witaminy D3 (25-OH-D3), hormonów steroidowych (np. androstendionu, aldosteronu, 17-OH-progesteronu), przeciwciał: przeciwko receptorowi TSH (TRAb, TSH receptor autoantibody), przeciwko tyreoperoksydazie (a-TPO) i przeciwko tyreoglobulinie (a-Tg). W tym typie testu podatnego na działanie biotyny (zawierającego układ SA/B) obserwuje się fałszywie dodatnie (zawyżone) wyniki stężenia/miana badanych hormonów i przeciwciał.

\section{Testy immunochemiczne wykorzystujące układ streptawidyna (awidyna)-biotyna — ich podatność na działanie interferencyjne biotyny}

Spośród siedmiu obecnie najczęściej stosowanych analizatorów immunochemicznych $\mathrm{w}$ sześciu $\mathrm{z}$ nich wykorzystano układ streptawidyna (awidyna)-biotyna. Do analizatorów podatnych na zakłócenia ze strony biotyny ze względu na wykorzystanie w nich układu streptawidyna (awidyna)-biotyna należą:

— Elecsys ${ }^{\circledR}$ (firmy Roche) — wszystkie 81 testów immunochemicznych;

- Vitros ${ }^{\circledR}$ (firmy Ortho) - 29 spośród 43 testów;

— Dimension ${ }^{\circledR}$ (firmy Siemens) - 21 spośród 26 testów;

- Centaur (firmy Siemens) - 18 spośród 67 testów;

— Access ${ }^{\circledR}$ i DXI® (firmy Beckman Coulter) - 14 spośród 48 testów;

— Architect i2000® (firmy Abbott) - 2 spośród 46 testów.

Wyjątek stanowi analizator Liaison XL® firmy DiaSorin, który wśród 42 dostępnych testów immunochemicznych nie oferuje żadnego testu wykorzystującego reakcję streptawidyna (awidyna)-biotyna. Podsumowując, spośród 353 dostępnych testów 165 może być wrażliwych na interferującą biotynę, co stanowi $47 \%$ wszystkich testów. W tabeli I przedstawiono testy immunochemiczne różnych producentów stosowane w laboratoryjnej diagnostyce zaburzeń endokrynnych, które są podatne na interferencję biotyny. Niektórzy producenci w ulotkach dołączanych do zestawów odczynników wymieniają biotynę jako jeden z czynników zakłócających oznaczenia. W zależności od producenta i rodzaju stosowanego testu progowe stężenie biotyny, powyżej którego będzie ona interferowała w oznaczenie, wynosi 2,4-1968 $\mu \mathrm{g} / \mathrm{l}(10-8200 \mathrm{nmol} / \mathrm{l})$ (wśród wcześniej wymienionych analizatorów) [12]. W większości testów próg ten wynosi < $51 \mu \mathrm{g} / 1$ [13]. Niestety, nie dla wszystkich testów te dane są dostępne, ponadto producenci nie informują, jakiej dawce 
Tabela I. Testy immunochemiczne stosowane w biochemicznej diagnostyce endokrynologicznej podatne na interferencje biotyny

\begin{tabular}{|c|c|c|c|c|}
\hline \multirow[b]{2}{*}{ Analizator } & \multicolumn{4}{|c|}{ Testy endokrynologiczne } \\
\hline & $\begin{array}{l}\text { Liczba } \\
\text { testów }\end{array}$ & $\begin{array}{l}\text { Liczba testów } \\
\text { podatnych na } \\
\text { interferencje } \\
\text { biotyny }\end{array}$ & $\begin{array}{c}\text { Stężenie, przy którym } \\
\text { biotyna interferuje } \\
\text { w oznaczenia testów } \\
{[\mu \mathrm{g} / \mathrm{l}]}\end{array}$ & Test i kierunek interferencji \\
\hline Roche Elecsys & 46 & 46 & $5,04-117,84$ & $\begin{array}{l}\mathrm{TSH} \downarrow \mathrm{TG} \downarrow \mathrm{FSH} \downarrow \mathrm{LH} \downarrow \mathrm{SHBG} \downarrow \mathrm{PTH} \downarrow \mathrm{PRL} \downarrow \mathrm{hCG} \downarrow \mathrm{fT} 4 \uparrow \\
\mathrm{T} 4 \uparrow \mathrm{fT} 3 \uparrow \mathrm{T} 3 \uparrow \mathrm{CORT} \uparrow \mathrm{E} 2 \uparrow \mathrm{PRG} \uparrow \text { Testost } \uparrow \mathrm{DHEAS} \uparrow \\
250 \mathrm{HD} \uparrow \mathrm{TGAb} \uparrow \mathrm{TPOAb} \uparrow \mathrm{TSHRAb} \uparrow\end{array}$ \\
\hline Ortho Vitros & 17 & 11 & $4,8-19,68$ & $\begin{array}{l}\text { TSH } \downarrow \text { FSH } \downarrow \text { LH } \downarrow \text { iPTH } \downarrow \text { PRL } \downarrow \text { hCG } \downarrow \text { PRG } \uparrow \text { E2 } \uparrow \text { Testost } \uparrow \\
\text { CORT } \uparrow 250 H D \uparrow\end{array}$ \\
\hline $\begin{array}{l}\text { Siemens } \\
\text { Dimension }\end{array}$ & 10 & 9 & $49,20-196,80$ & $\overline{\mathrm{TSH}} \downarrow$ FSH $\downarrow$ LH $\downarrow$ PRL $\downarrow$ hCG $\downarrow$ fT4 4 fT3个 PRG个 Testost $\uparrow$ \\
\hline Siemens Centaur & 20 & 4 & $98,16-981,60$ & 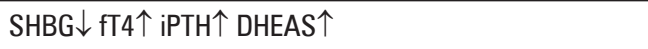 \\
\hline $\begin{array}{l}\text { Beckman Coulter } \\
\text { Access/DXI }\end{array}$ & 26 & 6 & $98,16-240,00$ & $\mathrm{TG} \downarrow \mathrm{TGAb} \downarrow \mathrm{TPOAb} \downarrow \mathrm{fT} 4 \uparrow \mathrm{fT} 3 \uparrow \mathrm{TT} 3 \uparrow$ \\
\hline $\begin{array}{l}\text { Abbott Architect } \\
\text { i2000 }\end{array}$ & 18 & 1 & Nieznany & $250 \mathrm{HD}$ \\
\hline DiaSorin Liaison XL & 20 & 0 & - & - \\
\hline
\end{tabular}

fT4 (free thyroxine) — wolna tyroksyna; T4 (thyroxine) — tyroksyna; fT3 (free triiodothyronine) — wolna trijodotyronina; T3 (triiodothyronine) — trijodotyronina; CORT — kortyzol; E2 — estradiol; PRG — progesteron; Testost — testosteron; DHEAS (dehydroepiandrosterone) — siarczan dehydroepiandrosteronu; $250 \mathrm{HD}$ - kalcyfediol; TGAb (thyroglobulin autoantibody) — przeciwciało przeciw tyreoglobulinie; TPOAb (anti-thyroid peroxidase autoantibody) — przeciwciało przeciwko tyreoperoksydazie; TSHRAb (TSH receptor antibody) — przeciwciało przeciw receptorom TSH; LH (/uteinizing hormone) — hormon lutenizujący; hCG (human chorionic gonadotropin) — gonadotropina kosmówkowa; FSH (follicle-stimulating hormone) — hormon folikulotropowy; PTH (parathyroid hormone) — parathormon; SHGB (sex hormone binding globulin) — globulina wiążąca hormony płciowe

witaminy przyjmowanej przez pacjenta odpowiadają te stężenia [4]. Bardziej szczegółowych informacji na temat wpływu różnych stężeń biotyny na oznaczenie wybranych parametrów dostarczył przeprowadzony na analizatorze Elecsys ${ }^{\circledR}$ (firmy Roche) eksperyment in vitro, w którym symulowano przyjęcie biotyny w dawkach 5-10 mg oraz 100-300 mg, co odpowiadało

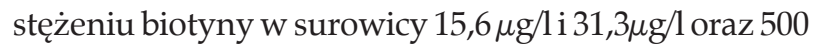
$\mu \mathrm{g} / \mathrm{l}$. Na niskie stężenia biotyny najbardziej wrażliwa była troponina $\mathrm{T}$ i przeciwciała przeciwtarczycowe, a w przypadku wysokich stężeń biotyny wszystkie testy okazały się znacząco podatne na interferencję ze strony tej witaminy. W eksperymencie wykazano dużą zmienność wrażliwości testów na zakłócenie spowodowane obecnością w surowicy biotyny oraz uzyskano dokładniejsze dane niż te zawarte w ulotce od producenta [14]. Eksperyment in vitro przeprowadzono także z użyciem analizatora Dimension ${ }^{\circledR}$ (firmy Siemens). Badano w nim wpływ różnych stężeń biotyny w próbkach pacjenta na wyniki testów immunodiagnostycznych. Przy stężeniu biotyny 50-200 $\mu \mathrm{g} / \mathrm{l}$ nie wykazano żadnych interferencji w oznaczeniach. Stężenie biotyny $300 \mu \mathrm{g} / \mathrm{l}$ interferowało w oznaczenie troponiny i fT3, powyżej $400 \mu \mathrm{g} / 1 \mathrm{w}$ oznaczeniach: troponiny, digoksyny, N-końcowego propeptydu natriuretycznego typu B (NT-pro-BNP, N-terminal pro b-type natriuretic peptide), fT3, fT4, TSH, progesteronu i estradiolu [15]. Choć wyniki obu eksperymentów dostarczają wielu cennych informacji, przeprowadzono je z użyciem „czystej” biotyny i mogą nie odzwierciedlać warunków, jakie istnieją w próbce pacjenta, w której oprócz samej biotyny występują też jej metabolity $[8,15,16]$.

Wystąpienie interferencji biotyny w procedurze testów immunodiagnostycznych zależy od kilku czynników: od konstrukcji testu immunologicznego, wielkości dawki, jaką przyjmuje pacjent, od stężenia biotyny w badanej próbce, a przede wszystkim od czasu, jaki upłynie od przyjęcia ostatniej dawki przez pacjenta do pobrania materiału do badań. W przypadku biotyny przyjmowanej razem z pożywieniem jej stężenie w surowicy wynosi 0,12-0,36 nmol/1 (0,0288-0,0864 $\mu \mathrm{g} / \mathrm{l})$ i nie zakłóca reakcji w testach $\mathrm{z}$ zastosowaniem układu SA/B $[5,17]$. Li i wsp. przeprowadzili badanie, w którym 6 zdrowych osób przez 7 dni przyjmowało biotynę $\mathrm{w}$ dawce $10 \mathrm{mg}$. Średnie wyjściowe stężenie biotyny wynosiło $0,774 \mu \mathrm{gl}(774 \mathrm{pg} / \mathrm{ml})$, a po 7 dniach $-3,6 \mu \mathrm{g} / 1$ (3600 pg/ml). W 7. dniu interferencję w oznaczeniach zaobserwowano w przypadku 39\% (9 spośród 23) badanych testów wykorzystujących układ SA/B. Natomiast po 7 dniach od zaprzestania przyjmowania biotyny nie odnotowano już żadnych zmian w wynikach [11]. Biotyna w pojedynczej dawce $30 \mathrm{mg}$ powoduje zakłócenia w oznaczeniach stężenia fT4, fT3 i tyreoglobuliny (analizator firmy Beckman Coulter), które utrzymują się do 24 godz. [18]. U pacjentki przyjmującej $100 \mathrm{mg}$ biotyny 3 razy dziennie stężenie TSH, T4, fT4, T3 powróciło do normy po 3 dniach [19]. Wśród dzieci i noworodków leczonych dawkami biotyny $15-20 \mathrm{mg} / \mathrm{kg} / \mathrm{dz}$. wyniki 
Tabela II. Wyniki stężenia hormonów tarczycy w obecności wysokiego stężenia biotyny [20]

\begin{tabular}{|c|c|c|c|c|c|c|}
\hline & Pacjent 1 & Pacjent 2 & Pacjent 3 & Pacjent 4 & Pacjent 5 & Pacjent 6 \\
\hline Płeć/wiek & $\mathrm{K} / 9$ lat & $\mathrm{K} / 2$ lat & $\mathrm{M} / 2$ lat & $\mathrm{M} / 5$ mies. & M / 1 mies. & $\mathrm{M} / 1$ mies. \\
\hline Dawka biotyny [mg/kg/dz.] & 10 & 14 & 15 & 2 & 7 & 8 \\
\hline \multicolumn{7}{|c|}{ Wyniki oznaczeń hormonalnych } \\
\hline \multicolumn{7}{|l|}{ Stosowanie biotyny } \\
\hline $\mathrm{TSH}[\mu \mathrm{lU} / \mathrm{ml}]$ & 0,05 & 0,02 & 0,04 & 0,02 & 0,08 & 0,03 \\
\hline $\mathrm{fT}_{4}[\mathrm{ng} / \mathrm{dl}]$ & 6,24 & $>7,77$ & $>7,77$ & $>7,77$ & $>7,77$ & $>7,77$ \\
\hline $\mathrm{T}_{3}[\mathrm{ng} / \mathrm{dl}]$ & $>6,5$ & - & $>6,5$ & $>6,5$ & $>6,5$ & - \\
\hline TRAb [IU/l] & 38,6 & $>40,0$ & $>40,0$ & $>40,0$ & $>40,0$ & $>40,0$ \\
\hline \multicolumn{7}{|c|}{ 1-7 dni po odstawieniu biotyny } \\
\hline $\mathrm{TSH}[\mu \mathrm{lU} / \mathrm{ml}]$ & 1,80 & 3,75 & 6,07 & 2,20 & 8,12 & 2,87 \\
\hline $\mathrm{fT}_{4}[\mathrm{ng} / \mathrm{dl}]$ & 1,58 & 1,70 & 1,16 & 1,13 & 1,84 & 1,91 \\
\hline $\mathrm{T}_{3}[\mathrm{ng} / \mathrm{dl}]$ & 2,0 & - & 1,8 & - & 1,8 & 2,3 \\
\hline TRAb [IU/I] & $<0,3$ & - & 0,7 & 1,0 & 0,4 & $<0,3$ \\
\hline
\end{tabular}

TSH (thyroid-stimulating hormone) — hormon tyreotropowy; fT4 (free thyroxine) — wolna tyroksyna; T3 (triiodothyronine) — trijodotyronina; TRAb (TSH receptor autoantibody) — przeciwciało przeciwko receptorowi TSH

stężenia TSH, fT4 i T3 unormowały się po 24-48 godz. od odstawienia biotyny, natomiast fałszywie podwyższone miano przeciwciał przeciwko receptorowi TSH utrzymywało się do 7 dni.

\section{Dlaczego interferencje biotyny są szczególnie istotne $w$ diagnostyce chorób tarczycy?}

Fałszywie zaniżone wyniki stężenia TSH, fałszywie podwyższone wyniki stężenia wolnych hormonów tarczycy i obecność przeciwciał przeciwko receptorowi TSH (TRAb) mogą sugerować nadczynność tarczycy bez wyraźnych objawów klinicznych. W tabeli II przedstawiono wyniki stężenia hormonów tarczycy w obecności wysokiego stężenia biotyny (opracowano na podstawie pracy Kummer i wsp. [20]).

\section{Interferencja biotyny w oznaczeniach hormonalnych - opisy przypadków}

W ostatnim okresie zaczęły ukazywać się artykuły przedstawiające przypadki interferencji biotyny w oznaczeniach immunochemicznych. Najczęściej są to pojedyncze prace opisujące konkretne przypadki kliniczne. Prace te obejmowały różne grupy wiekowe: od noworodków po osoby w zaawansowanym wieku. W znacznej części dotyczyły nieprawidłowych wyników oznaczeń stężenia hormonów tarczycy (fT4, fT3) i stężenia TSH [17-25], ale również stężenia PTH, kortykotropiny (ACTH, adrenocorticotropic hormone), prolaktyny, testosteronu, kortyzolu i estradiolu [6, 16, 26]. Doniesienia te były na tyle liczne, że w listopadzie
2017 roku amerykańska Agencja ds. Żywności i Leków (FDA, Food and Drug Administration) wydała komunikat ostrzegawczy dotyczący możliwości interferencji biotyny w oznaczenia immunochemiczne. W opublikowanym raporcie szczególnie niepokojąca była informacja o śmierci jednego pacjenta, u którego wyniki stężenia troponiny (markera martwicy kardiomiocytów) we krwi były błędne - fałszywie zaniżone w teście wykorzystującym układ SA/B. Pacjent ten przyjmował wysokie dawki biotyny. Zdarzenie to uwidacznia, jak poważne konsekwencje mogą wynikać z uzyskania nieprawidłowych wyników badań, spowodowanych obecnością egzogennej biotyny w badanej próbce [27].

Arya i wsp. opisują przypadek czterech noworodków, którym podano biotynę w związku z podejrzeniem wrodzonej choroby metabolicznej. U wszystkich zaobserwowano nieprawidłowe stężenia hormonów tarczycy przy braku objawów klinicznych wskazujących na tyreotoksykozę (analizator firmy Roche Diagnostics). U trzech noworodków po wykluczeniu podejrzenia choroby metabolicznej zaprzestano podawania biotyny. Wszystkie wyniki wróciły do normy. W przypadku jednego noworodka, u którego dalej kontynuowano podawanie biotyny, wyniki stężenia hormonów tarczycy oznaczone z wykorzystaniem innego analizatora (analizator Centaur, firmy Siemens) mieściły się w zakresie referencyjnym [9]. U 3-letniej dziewczynki z kwasicą propionową w celu dalszej diagnostyki zlecono badanie hormonów tarczycy. Stężenie TSH było poniżej normy, a stężenia fT4 i fT3 mieściły się w zakresie referencyjnym (analizator firmy Roche Diagnostics). Objawy kliniczne pacjentki nie wskazywały na tyreotoksykozę, dlatego zlecono 
powtórzenie badań na innym analizatorze, na którym wynik stężenia TSH okazał się w normie, natomiast stężenia fT4 i fT3 były znacząco podwyższone (analizator firmy Beckman Coulter). Pacjentkę tą leczono biotyną w dawce $10 \mathrm{mg} 4$ razy dziennie, a przyczyną różnic w oznaczeniach był fakt, że nie wszystkie użyte testy wykorzystywały układ SA/B (oznaczenie stężenia TSH, analizator firmy Beckman Coulter) [17]. W maju 2018 roku ukazał się artykuł opisujący przypadek 47-letniego mężczyzny ze stwardnieniem rozsianym, który przyjmował biotynę w dawce 300 mg/dzień. Zlecone badania funkcji tarczycy wskazywały na nadczynność (znacznie obniżone TSH i podwyższone stężenie fT4 i fT3), a w połączeniu z podwyższonymi mianami przeciwciał a-TPO i TRAb sugerowały chorobę Gravesa-Basedowa (G-B). W związku z tym, że $\mathrm{u}$ pacjenta nie występowały żadne objawy kliniczne nadczynności tarczycy, zlecono powtórzenie badań po 2 tygodniach od zaprzestania przyjmowania biotyny. Wszystkie wyniki z wyjątkiem TRAb wróciły do normy [28]. Interferencja biotyny w testy immunochemiczne u dwóch innych pacjentów powodowała, że wyniki badań również wskazywały na chorobę G-B [23, 29, 30], a w jednym dodatkowo na hiperestrogenizm [6]. W połowie 2018 roku u 48-letniej pacjentki zlecono dodatkowe badania hormonalne w związku z hirsutyzmem, zwiększeniem wagi oraz podejrzeniem choroby tarczycy. U chorej stwierdzono podwyższone stężenie testosteronu i kortyzolu oraz obniżone stężeniem ACTH i prolaktyny (analizatory firm: Roche Diagnostics i OCD Vitros). W celu dalszej diagnostyki zlecono badania obrazowe: rezonans magnetyczny (MRI, magnetic resonance imaging) i tomografię komputerową (TK). Badania te nie potwierdziły podejrzenia nieczynnego gruczolaka oraz choroby nadnerczy. W związku z podwyższonym steżeniem testosteronu, podejrzewano nowotwór jajnika wydzielający testosteron i niepotrzebnie wykonano histerektomię z owariektomią. Natomiast po oznaczeniu wolnego i całkowitego testosteronu z użyciem wysokosprawnej chromatografii cieczowa sprzężona $\mathrm{z}$ tandemowym spektrometrem mas (LC-MS/MS, liquid chromatography-tandem mass spectrometry) okazało się, że wyniki są prawidłowe. Po odstawieniu suplementu biotyny (przyjmowana dawka $5 \mathrm{mg} / \mathrm{dz}$.) na okres 2 tygodni wartości większości parametrów laboratoryjnych (oprócz TSH) wróciły do normy. Po oznaczeniu stężenia TSH na innym analizatorze okazało się, że również ten wynik mieści się w zakresie wartości referencyjnych (TSH $-1,1 \mathrm{mIU} / \mathrm{ml}$, analizator firmy Beckman Coulter), a klinicznie u pacjentki potwierdzono eutyreozę [31]. Interferencje biotyny opisywano także w przypadku oznaczenia stężenia PTH [16, 26]. Fałszywie zaniżone stężenie PTH stwierdzono u dwóch pacjentek: 60-letniej i 62-letniej, przyjmujących odpowiednio po 1,5 mg i $5 \mathrm{mg}$ biotyny [26].

W tabeli III przedstawiono wyniki oznaczeń hormonalnych pacjentów, u których stwierdzono obecność interferencji w związku ze stosowaniem różnych dawek biotyny (opracowano na podstawie pracy Samarasinghe i wsp. [12]).

Testy immunochemiczne ze względu na swoją specyfikę, wykorzystującą interakcję przeciwciał z antygenami, są podatne także na interferencje ze strony przeciwcial, które wykazują powinowactwo do składników testu. Procedurę takich testów mogą zakłócać przeciwciała przeciwko streptawidynie [32, 33] albo przeciwciała heterofilne oddziałujące z biotyną [34, 35], przeciwciała przeciw mysim IgG [36], przeciwciała przeciwko rutenowi [37], przeciwciała przeciwko biotynie [38].

\section{Podsumowanie}

Otrzymanie fałszywie zaniżonych lub fałszywie zawyżonych wyników stężenia hormonów w następstwie interferencji biotyny $\mathrm{w}$ testach immunochemicznych wykorzystujących układ SA/B może skutkować postawieniem błędnej diagnozy i zastosowaniem nieprawidłowego leczenia, narażeniem pacjenta na długotrwały stres oraz na niepotrzebne dodatkowe badania laboratoryjne i obrazowe, które podwyższają koszty leczenia. Zarówno lekarze, jak i diagności laboratoryjni powinni wspólnie działać na rzecz wyeliminowania tego problemu.

Do działań, jakie powinien podjąć lekarz w celu ograniczenia wystąpienia interferencji biotyny, należą:

- pozyskanie informacji o stosowanych suplementach diety zawierających biotynę podczas wywiadu z pacjentem (stosowana dawka, czas przyjmowania preparatu biotyny);

- kontakt z laboratorium - ustalenie, czy dany test diagnostyczny i w jakim stopniu test jest podatny na interferencje z biotyną;

- w przypadku informacji zebranych podczas wywiadu lekarskiego wskazujących na stosowanie przez pacjenta preparatów z biotyną - zlecenie badań laboratoryjnych po okresie zaprzestania ich przyjmowania; w zależności od czasu i stosowanej dawki biotyny okres ten powinien wynosić od jednego (w przypadku małych dawek) do 3-7 dni (wyższe dawki), należy przy tym pamiętać o indywidualnych, osobniczych różnicach, mogących wpływać na wynik badania laboratoryjnego;

- w przypadku niezgodności wyników badań laboratoryjnych z obrazem klinicznym - wykonanie oznaczenia testem immunochemicznym innego producenta, który w swojej konstrukcji nie zawiera 
Tabela III. Wyniki stężenia hormonów u pacjentów ze stwierdzonq interferencjq w zwiq̨zku ze stosowaniem różnych dawek biotyny [12]

\begin{tabular}{|c|c|c|c|c|c|}
\hline Lp. & Autor i rok & $\begin{array}{l}\text { Wiek i płeć } \\
\text { pacjenta }\end{array}$ & Dawka biotyny & $\begin{array}{l}\text { Zmiany w badaniach } \\
\text { laboratoryjnych }\end{array}$ & Analizator immunochemiczny \\
\hline 1 & Koehler i wsp. 2018 & 47-letni mężczyzna & $300 \mathrm{mg} / \mathrm{dz}$ & $\begin{array}{l}\downarrow \text { TSH } \uparrow f T 4 \text { 个fT3 } \uparrow T P O A b \\
\uparrow T R A b\end{array}$ & No data \\
\hline 2 & Stieglitz i wps. 2018 & 48-letnia kobieta & $5 \mathrm{mg} / \mathrm{dz}$ & $\begin{array}{l}\downarrow T S H \downarrow A C T H \downarrow P R L \\
\uparrow T E S T O \uparrow C O R T\end{array}$ & $\begin{array}{l}\text { Roche Cobes e601 OCD Vitros } 5600 \\
\text { Beckman Coulter UniCel Dxl } 800\end{array}$ \\
\hline 3 & Evans i wps. 2018 & $\begin{array}{l}\text { 15-miesięczny } \\
\text { chłopiec }\end{array}$ & $15-100 \mathrm{mg} / \mathrm{dz}$. & $\leftrightarrow \mathrm{TSH} \uparrow \mathrm{fT} 4$ & Beckman Coulter Dxl \\
\hline 4 & Arya i wsp. 2018 & $\begin{array}{l}9 \text { miesięcy } \\
\text { dziewczynka }\end{array}$ & $2,5 \mathrm{mg} / \mathrm{kg} / \mathrm{dz}$ & $\downarrow T S H$ 个fT4 $\uparrow f T 3$ & Roche Diagnostics \\
\hline 5 & Arya i wsp. 2018 & $\begin{array}{l}9 \text { miesięcy } \\
\text { dziewczynka }\end{array}$ & $2,5 \mathrm{mg} / \mathrm{kg} / \mathrm{dz}$ & $\downarrow T S H$ 个fT4 $\uparrow f T 3$ & Roche Diagnostics \\
\hline 6 & Arya i wsp. 2018 & $\begin{array}{l}<1 \text { miesiąc } \\
\text { chtopiec }\end{array}$ & $4 \mathrm{mg} / \mathrm{kg} / \mathrm{dz}$ & $\downarrow T S H$ 个fT4 $\uparrow f T 3$ & Roche Diagnostics Siemens Centaur \\
\hline 7 & Arya i wsp. 2018 & $\begin{array}{l}<1 \text { miesiąc } \\
\text { chtopiec }\end{array}$ & $5,2 \mathrm{mg} / \mathrm{kg} / \mathrm{dz}$ & $\downarrow$ TSH $\uparrow f T 4 ~ \uparrow f T 3$ & Roche Diagnostics \\
\hline 8 & Cusini i wsp. 2017 & 69-letnia kobieta & $100 \mathrm{mg} / 3 \times \mathrm{dz}$ & $\downarrow T S H$ 个fT4 $\uparrow f T 3$ & Roche Diagnostics \\
\hline 9 & Willeman i wsp. 2017 & 39-letni mężczyzna & $50 \mu \mathrm{g} / \mathrm{dz}$ & $\downarrow \mathrm{TSH} \leftrightarrow \mathrm{fT} 4 \leftrightarrow \mathrm{fT} 3$ & $\begin{array}{l}\text { Siemens Dimension Vista } 1500 \\
\text { Intelligent Lab System }\end{array}$ \\
\hline 10 & Sulaiman 2016 & 3 pacjentów & $1-10 \mathrm{mg} / \mathrm{kg} / \mathrm{dz}$ & $\begin{array}{l}\downarrow T S H \text { 个fT4 } \uparrow \text { fT } 3 \leftrightarrow \text { TSH } \\
\leftrightarrow \mathrm{fT} 4 \leftrightarrow \mathrm{fT} 3\end{array}$ & $\begin{array}{l}\text { Roche Modular Cobas } 602 \text { Abbott } \\
\text { Architect I-2000 }\end{array}$ \\
\hline 11 & Minkovsky i wsp. 2016 & 74-letnia kobieta & $100 \mathrm{mg} / 3 \times \mathrm{dz}$ & $\downarrow T S H$ 个fT4 $\uparrow \mathrm{fT} 3$ & Roche Diagnostics \\
\hline 12 & Kummer i wsp. 2016 & $\begin{array}{l}\text { 9-letnia } \\
\text { dziewczynka }\end{array}$ & $10 \mathrm{mg} / \mathrm{kg} / \mathrm{dz}$ & $\downarrow$ TSH $\uparrow f T 4 ~ \uparrow T 3 ~ \uparrow T R A b$ & Roche Diagnostics \\
\hline 13 & Kummer i wsp. 2016 & $\begin{array}{l}\text { 2-letnia } \\
\text { dziewczynka }\end{array}$ & $14 \mathrm{mg} / \mathrm{kg} / \mathrm{dz}$ & $\downarrow$ TSH $\uparrow$ fT4 4 TRAb & Roche Diagnostics \\
\hline 14 & Kummer i wsp. 2016 & 2-letni chłopiec & $15 \mathrm{mg} / \mathrm{kg} / \mathrm{dz}$. & $\downarrow$ TSH $\uparrow f T 4 ~ \uparrow T 3 ~ \uparrow T R A b$ & Roche Diagnostics \\
\hline 15 & Kummer i wsp. 2016 & $\begin{array}{l}\text { 5-miesięczny } \\
\text { chłopiec }\end{array}$ & $2 \mathrm{mg} / \mathrm{kg} / \mathrm{dz}$ & $\downarrow$ TSH $\uparrow f T 4 ~ \uparrow T 3 ~ \uparrow T R A b$ & Roche Diagnostics \\
\hline 16 & Kummer i wsp. 2016 & $\begin{array}{l}\text { 1-miesięczny } \\
\text { chłopiec }\end{array}$ & $7 \mathrm{mg} / \mathrm{kg} / \mathrm{dz}$ & $\downarrow T S H$ 个fT4 $\uparrow T 3$ 个TRAb & Roche Diagnostics \\
\hline 17 & Kummer i wsp. 2016 & $\begin{array}{l}\text { 1-miesięczny } \\
\text { chłopiec }\end{array}$ & $8 \mathrm{mg} / \mathrm{kg} / \mathrm{dz}$ & $\downarrow T S H$ 个fT4 $\uparrow$ TRAb & Roche Diagnostics \\
\hline 18 & Batista i wsp. 2016 & 52-letnia kobieta & $10 \mathrm{mg} / \mathrm{dz}$ & $\begin{array}{l}\downarrow T S H \leftrightarrow f T 4 \leftrightarrow \text { fT3 } \\
\uparrow \text { ESTRADIOL TRAb }+\end{array}$ & $\begin{array}{l}\text { OCD Vitros } 5600 \text { Roche E170/Cobas } \\
602 \text { Modular }\end{array}$ \\
\hline 19 & Elston i wps. 2016 & 63-letnia kobieta & $100 \mathrm{mg} / 3 \times \mathrm{dz}$ & $\begin{array}{l}\downarrow \text { TSH } \uparrow f T 4 \text { 个fT3 } \uparrow \text { TRAb } \\
\leftrightarrow \text { TSH } \uparrow \text { FT4 } \uparrow \text { fT3 } \\
\end{array}$ & $\begin{array}{l}\text { Roche Diagnostics Cobas } 6000 \\
\text { Beckman Coulter Dxl }\end{array}$ \\
\hline 20 & Barbesio 2016 & 55-letni mężczyzna & $100 \mathrm{mg} / 3 \times \mathrm{dz}$ & $\downarrow$ TSH $\uparrow f T 4$ 个fT3 个TRAb & Roche Diagnostics Elecsys \\
\hline 21 & Waghray i wsp. 2013 & 60-letnia kobieta & $1,5 \mathrm{mg} / \mathrm{dz}$ & $\downarrow$ PTH & $\begin{array}{l}\text { Siemens Advia Centaur Roche } \\
\text { Cobas E411 }\end{array}$ \\
\hline 22 & Waghray i wsp. 2013 & 62-letnia kobieta & $5 \mathrm{mg} / \mathrm{dz}$ & $\downarrow$ PTH & $\begin{array}{l}\text { Siemens Advia Centaur Roche } \\
\text { Cobas E411 }\end{array}$ \\
\hline 23 & Wijeratne 2012 & $\begin{array}{l}\text { 1-tygodniowe } \\
\text { dziecko }\end{array}$ & $30 \mathrm{mg} / \mathrm{dz}$. & $\leftrightarrow \mathrm{TSH} \uparrow \mathrm{fT} 4$ 个fT3 & Beckman Coulter Dxl \\
\hline 24 & Kwok i wsp. 2012 & $\begin{array}{l}\text { 3-letnia } \\
\text { dziewczynka }\end{array}$ & $10 \mathrm{mg} / 4 \times \mathrm{dz}$ & $\begin{array}{l}\downarrow \mathrm{TSH} \leftrightarrow \mathrm{fT} 4 \leftrightarrow \mathrm{fT} 3 \\
\leftrightarrow \mathrm{TSH} \text { 个fT4 } \uparrow \mathrm{fT} 3\end{array}$ & $\begin{array}{l}\text { Roche Cobas e601 Beckman } \\
\text { Coulter Access }\end{array}$ \\
\hline 25 & Meany i wsp. 2009 & 64-letnia kobieta & 10 mg/dz. & $\downarrow$ PTH & Roche Elecsys 2010 \\
\hline 26 & Henry i wsp. 1996 & Noworodek & $10 \mathrm{mg} / \mathrm{dz}$ & $\downarrow \mathrm{TSH} \uparrow \mathrm{fT} 4$ & Boehringer Mannheim ES700 \\
\hline
\end{tabular}

TSH (thyroid-stimulating hormone) — hormon tyreotropowy; fT4 (free thyroxine) — wolna tyroksyna; fT3 (free triiodothyronine) — wolna trijodotyronina;

TPOAb (anti-thyroid peroxidase autoantibody) — przeciwciało przeciwko tyreoperoksydazie; TRAb (TSH receptor autoantibody) — przeciwciało przeciwko receptorowi TSH; ACTH (adrenocorticotropic hormone) — kortykotropina; PRL — prolaktyna; TESTO — testosteron; CORT — kortyzol; PTH (parathyroid hormone) — parathormon 


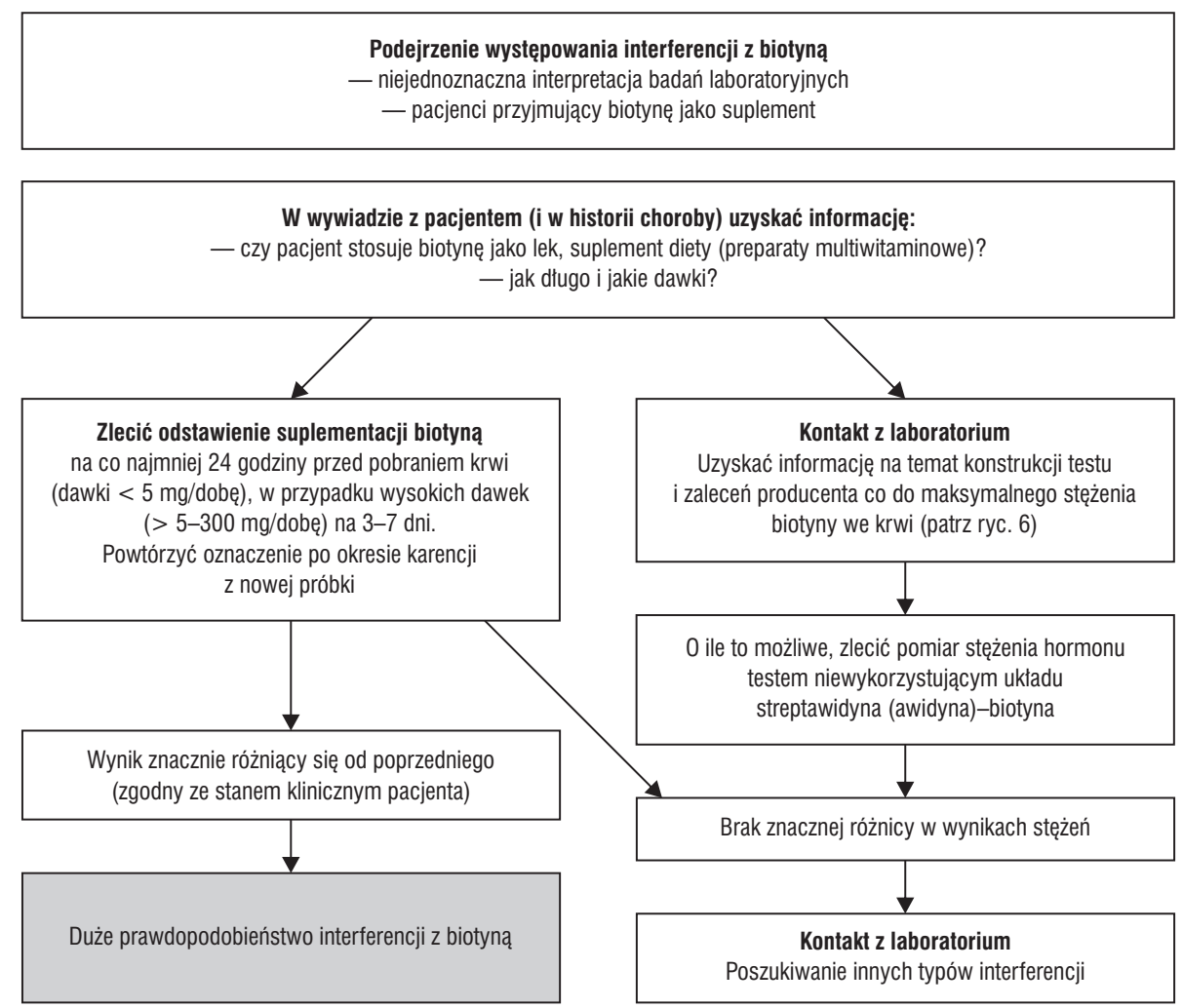

Rycina 5. Algorytm postępowania w przypadku podejrzenia interferencji biotyny dla lekarza klinicysty

układu streptawidyna (awidyna)-biotyna. W takim przypadku lekarz powinien skontaktować się z laboratorium w celu ustalenia ośrodka (laboratorium), który korzysta z testów diagnostycznych niewykorzystujących układu SA/B;

- w przypadku gdy wynik badania (powtórzony innym testem) jest nadal niezgodny z obrazem klinicznym - rozważenie innej przyczyny interferencji w oznaczeniach immunochemicznych — ponowny kontakt $\mathrm{z}$ laboratorium.

Na rycinie 5 przedstawiono algorytm postępowania $\mathrm{w}$ przypadku podejrzenia interferencji biotyny dla lekarza klinicysty.

Działania, jakie powinno podjąć medyczne laboratorium diagnostyczne $\mathrm{w}$ celu analizy wystąpienia interferencji biotyny:

- oznaczenie stężenia biotyny w próbce pacjenta przed wykonaniem właściwego badania nie jest możliwe, ponieważ obecnie nie są dostępne w pełni zautomatyzowane testy do oceny stężenia biotyny, które mogłyby być użyte podczas rutynowej pracy w laboratorium;

- w ostatnim okresie opracowano metodę pozwalającą na usunięcie $z$ badanej próbki nadmiaru egzogennej biotyny, która może potencjalnie interferować w oznaczeniach immunochemicz- nych $[8,40]$. Polega ona na wstępnym dodaniu do próbki surowicy pacjenta odpowiedniej ilości mikrocząsteczek opłaszczonych streptawidyną (uzyskanych ze zużytych odczynników). Następnie mieszanina jest inkubowana (z wytrząsaniem) przez 45 minut w temperaturze pokojowej. Po wirowaniu w zebranym supernatancie oznaczany jest wybrany parametr laboratoryjny [8, $39,40]$. Choć cała procedura nie jest kosztowna (wykorzystywane są odczynniki, które i tak były przeznaczone do utylizacji), a czas wykonania wynosi około 1 godz., to trudno będzie zastosować tę metodę podczas rutynowej pracy w laboratorium. Inną metodą usunięcia biotyny z badanej próbki może być użycie metody chromatografii powinowactwa. Obie metody nie są obecnie powszechnie stosowane i wymagają od laboratorium pewnego doświadczenia w identyfikowaniu różnego typu interferencji;

- wskazane jest, aby laboratorium opracowało własny algorytm postępowania w przypadkach podejrzenia interferencji biotyny: stosowanie testów niezawierających układów $\mathrm{SA} / \mathrm{B}$, dostęp do manualnych metod izotopowych, metod chromatograficznych (zwłaszcza LC/MS/MS) lub — najczęściej — współpraca z laboratorium korzystającym z metod 


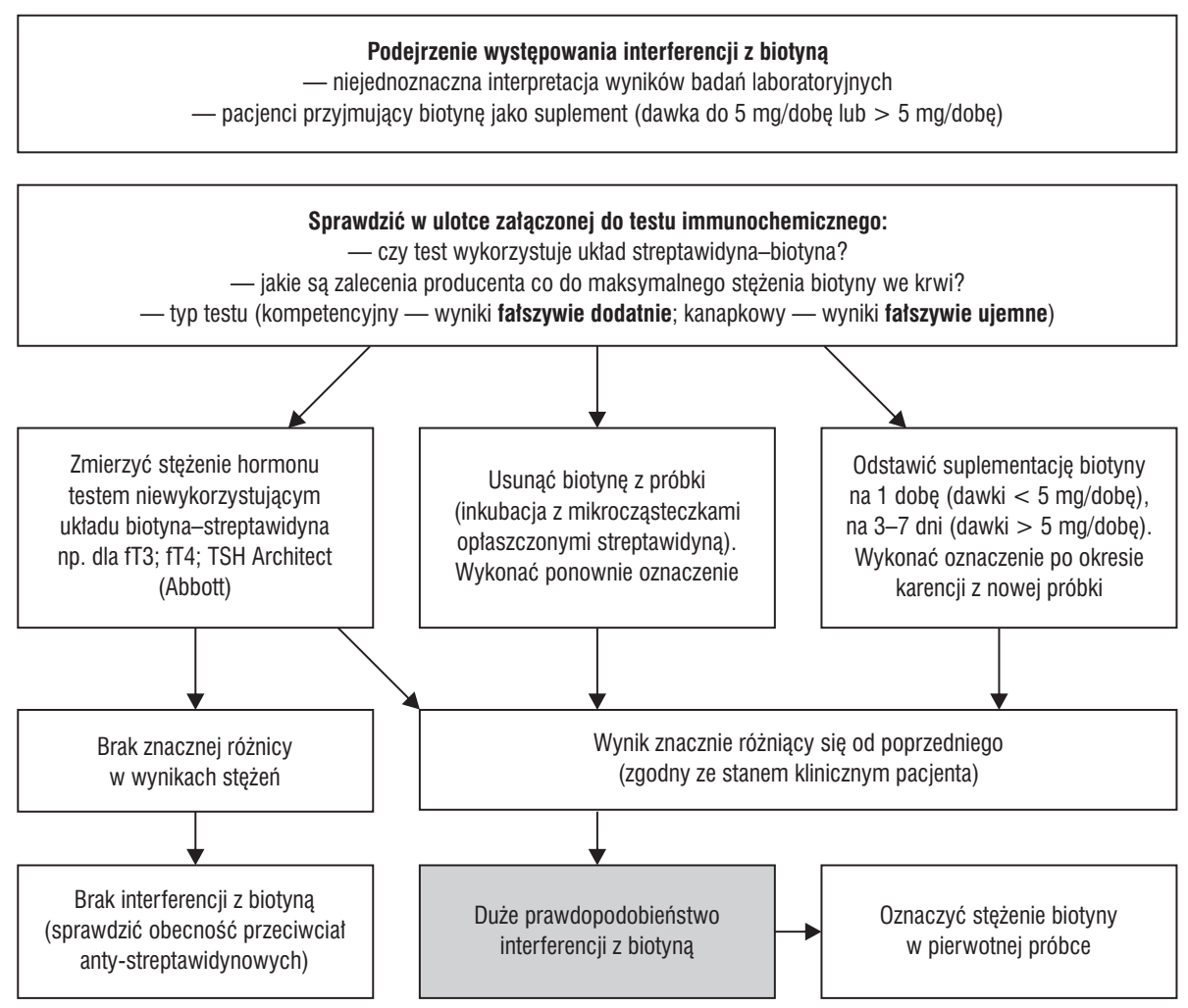

Rycina 6. Algorytm postępowania w przypadku podejrzenia interferencji biotyny dla diagnosty laboratoryjnego

(automatycznych, manualnych) niepodatnych na interferencje biotyny;

- poszukiwanie innych typów interferencji (np. obecność przeciwciał anty-streptawidynie, przeciwciał heterofilnych, makrocząsteczek hormonów itd.).
Na rycinie 6 przedstawiono algorytm postępowania $\mathrm{w}$ przypadku podejrzenia interferencji biotyny dla diagnosty laboratoryjnego.

\section{Wspótautorstwo pracy}

M.O. i Z.B. - równy udział w pracy. 